\title{
Unprecedented C-Selective Interstrand Cross-Linking through in Situ Oxidation of Furan-Modified Oligodeoxynucleotides
}

\author{
Marieke Op de Beeck and Annemieke Madder* \\ Laboratory for Organic and Biomimetic Chemistry, University of Ghent, Krijgslaan 281 S4, B-9000 Ghent, Belgium \\ Supporting Information
}

ABSTRACT: Chemical reagents that form interstrand cross-links have been used for a long time in cancer therapy. They covalently link two strands of DNA, thereby blocking transcription. Cross-link repair enzymes, however, can restore the transcription processes, causing resistance to certain anti-cancer drugs. The mechanism of these cross-link repair processes has not yet been fully revealed. One of the obstacles in this study is the lack of sufficient amounts of well-defined, stable, cross-linked duplexes to study the pathways of cross-lin moiety is incorporated into oligodeoxynucleotides (ODNs). These furan-modified nucleic acids can form interstrand crosslinks upon selective furan oxidation with $\mathrm{N}$-bromosuccinimide. We here report on the incorporation of the furan moiety at the $2^{\prime}$-position of a uridine through an amido or ureido linker. The resulting modified ODNs display an unprecedented selectivity for cross-linking toward a cytidine opposite the modified residue, forming one specific cross-linked duplex, which could be isolated in good yield. Furthermore, the structure of the formed cross-linked duplexes could be unambiguously characterized.

\section{INTRODUCTION}

The high specificity with which oligonucleotides recognize nucleic acids has led to considerable interest in the design of modified oligonucleotides. ${ }^{1}$ These customized nucleic acid derivatives can be used for a range of therapeutic and analytical purposes, including the treatment of diseases (antisense, ${ }^{2-4}$ siRNA $^{5-8}$ ), the regulation of gene expression (antigene, ${ }^{9-11}$ decoy $\mathrm{DNA}^{12,13}$ ), the investigation of RNA tertiary structures, ${ }^{14-16}$ and the study of DNA damage and the resulting repair processes. ${ }^{17-21}$

DNA is not indefinitely stable, and numerous sources of DNAdamaging agents of endogenous and exogenous origin contribute further to the instability of DNA. ${ }^{22}$ DNA interstrand cross-links (ICLs) are among the most cytotoxic lesions known, the covalent bond between the two DNA strands prohibiting strand separation and thereby blocking vital aspects of DNA metabolism. ICLs are mostly formed by reaction of cellular DNA with bifunctional electrophilic compounds that are either formed endogenously (e.g., lipid peroxidation) or present through exogenous exposure. ${ }^{23}$ Additionally, generation of an abasic site in the DNA upon depurination can also give rise to ICL formation. ${ }^{20,24}$

The cytotoxic properties of such ICL-forming agents are exploited by cancer chemotherapeutics, where their toxicity ultimately leads to apoptosis of the malignant cells. ${ }^{25}$ Development of resistance of the tumor cells to treatment with antitumor drugs can often be attributed to enhanced ICL repair. ${ }^{23}$ These repair pathways find their evolutionary origin in the necessity to counteract the threat posed by endogenous and exogenous crosslinking compounds, and failure to repair these lesions can lead to inherited disorders such as Fanconi anemia. ${ }^{23}$ Thus, although DNA repair is essential for a healthy cell, repair enzymes counteract the efficacy of a number of important antitumor agents whose therapeutic potential rests on the formation of ICLs. Therefore, selective inhibition of DNA repair in cancerous cells may greatly improve antitumor therapy, making DNA repair enzymes a promising target for drug design. In this context, understanding of the mechanisms of repair enzymes should significantly increase our understanding of the molecular basis of human disease. Significant progress has been made to elucidate the diverse DNA repair pathways, but the exact mechanisms underlying the repair of ICLs still remain poorly understood. ${ }^{26} \mathrm{~A}$ major factor limiting this research is the availability of short, well-defined, cross-linked oligodeoxynucleotides (ODNs) as substrates for these repair enzymes. ${ }^{26}$ Interstrand cross-linked ODNs can be generated by treating dsDNA with bifunctional alkylating agents.

Received: June 2, 2010

Published: December 16, 2010 


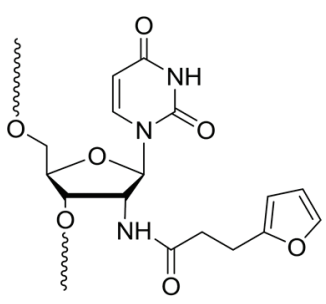

1

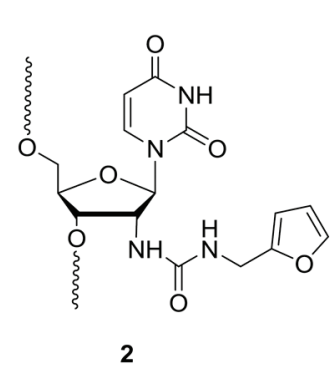

2

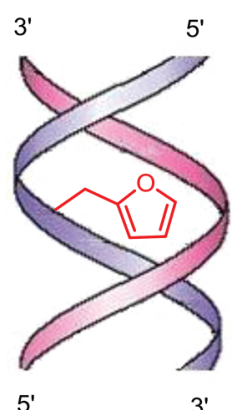

$3^{\prime}$

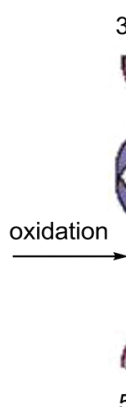

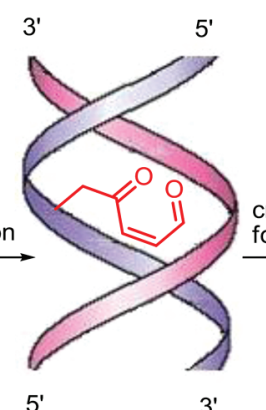

$3^{\prime}$

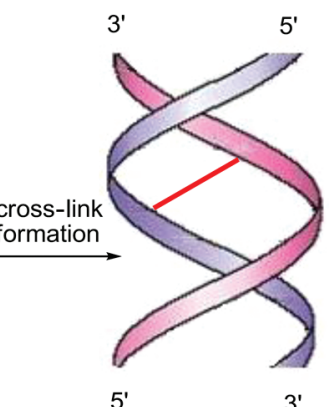

Figure 1. Building blocks for the synthesis of furan-modified ODNs. Selective in situ oxidation is followed by instantaneous interstrand cross-link formation.

However, as most alkylating agents offer little to no sequence selectivity and produce a mixture of mono adducts and intraand interstrand cross-links, only very low yields of the desired ICL are obtained (typically $<10 \%) .{ }^{27}$ The selectivity problem can be circumvented by inducing the ICL at a specific position in the duplex. In a first approach, a cross-linked dinucleotide can be incorporated in the DNA duplex..$^{18,28-31}$ This approach is, however, somewhat limited due to the need for up to three different orthogonal protecting groups on the dimer phosphoramidite. In an alternative approach, oligonucleotides are equipped with a reactive functionality, allowing crosslink formation after hybridization with their complementary strand. ${ }^{12,24,32-42}$ Depending on the specific chemistry employed, only one or both strands of the duplex contain a modified nucleoside. These modified residues can either be intrinsically reactive or contain a latent functionality that is activated by means of a triggering signal.

Although considerable effort has been devoted to the synthesis of cross-linked ODNs, few methods exist today that offer an efficient, high-yielding, and selective method for the generation of site-specifically cross-linked duplexes.

Here we present a cross-linking strategy inspired by the natural toxicity of furan, where a furan unit is inserted at the $2^{\prime}$-position of a uridine as a masked reactive $\gamma$-keto-enal. After hybridization of an ODN containing a 2 -furan-modified uridine with its complement, selective in situ oxidation of the furan unit to a reactive dicarbonyl moiety leads to fast and efficient generation of an interstrand cross-linked duplex (Figure 1). In continuation of our earlier preliminary studies, ${ }^{43}$ the furan moiety was introduced into the oligonucleotides by incorporation of $2^{\prime}$-modified uridine residues, presenting the furan moiety through an amide (1) or ureide (2) linker. A detailed investigation of sequence selectivity and linker influence has been carried out, and thorough structural characterization has now shed light on the cross-linking mechanism.

\section{RESULTS AND DISCUSSION}

Synthesis of the Modified Nucleosides. Coupling of furan onto uridine through an amide linker could be accomplished by coupling activated ester 5 with $2^{\prime}$-azido-uridine 8 (Scheme 1). A three-carbon linker was selected in view of the commercial availability of furan-2-acrylic acid 3. The necessary pentafluorophenyl ester was synthesized by hydrogenation of $\mathbf{3}$, followed by conversion of the obtained carboxylic acid 4 to the activated ester with pentafluorophenol.

The precursor $2^{\prime}$-azido-uridine was synthesized by conversion of uridine to the ring-closed intermediate $7^{44}$ and subsequent
$\mathrm{S}_{\mathrm{N}} 2$ substitution with an in situ-generated azide nucleophile, resulting in the formation of the desired $2^{\prime}$-azido-uridine $8{ }^{45}$ which could be coupled to activated ester 5 in a StaudingerVilarrasa coupling. ${ }^{46}$ Protection of the $5^{\prime}$-hydroxyl group and conversion of the nucleoside to phosphoramidite 10 were performed by standard methods.

The $2^{\prime}$-ureido-modified uridine $\mathbf{1 3}$ was synthesized by coupling of $2^{\prime}$-amino-uridine $\mathbf{1 1}$ to the commercially available furfurylisocyanate 12. In this way, a similar three-atom linker between the $2^{\prime}-\mathrm{N}$ and the furan moiety was obtained. The $2^{\prime}$-amino-uridine was obtained by reduction of $2^{\prime}$-azido-uridine 8 ; a Staudinger reduction ${ }^{47}$ was used rather than hydrogenation with $\mathrm{Pd} / \mathrm{C}^{48}$ to avoid reduction of the uracil base. ${ }^{49,50} \mathrm{DMTr}$ protection of the $2^{\prime}$-ureido-uridine $\mathbf{1 3}$ and subsequent conversion to the desired phosphoramidite yielded the necessary building block for incorporation into ODN by automated DNA synthesis.

ODN Synthesis. ODN synthesis was carried out on an automated DNA synthesizer, introducing a manual coupling step for the modified phosphoramidites to prevent loss of precious modified phosphoramidite in the tubing of the DNA synthesizer. Additionally, dicyanoimidazole (DCI) was used instead of tetrazole as a more potent activator for the manual couplings. Using our previously established standard conditions ${ }^{51}$ for the introduction of the $2^{\prime}$-modified uridines 10 and $\mathbf{1 4}$, initially a poor coupling efficiency was observed for the $2^{\prime}$-amido derivative $\mathbf{1 0}$, and no incorporation at all was observed for the $2^{\prime}$-ureido derivative 14. We speculated this to be due to the presence of a nucleophile at the $2^{\prime}$-position that was able to attack the activated phosphoramidite (Scheme 2). A similar explanation has been put forward by Al-Rawi and co-workers when encountering problems with a $2^{\prime}$-amido-derivatized phosphoramidite. ${ }^{52}$ If this holds true, then coupling efficiency should improve upon activating the phosphoramidite once the growing ODN chain is present. Indeed, by mixing the activator and the phosphoramidite on the synthesis column, satisfying coupling efficiency was observed for the $2^{\prime}$-amido- as well as the $2^{\prime}$-ureido-furan-modified nucleosides. The synthesized DMTr-protected ODNs were deprotected and purified on a SEP-PAK column and characterized by reversed-phase high-performance liquid chromatography (RP-HPLC) and electrospray ionization mass spectrometry (ESI-MS) (see Supporting Information).

Duplex Stability and Cross-Linking Selectivity. In order to assess the cross-linking selectivity of $2^{\prime}$-amido- and $2^{\prime}$-ureidofuran-modified ODN, phosphoramidites 10 and 14 were incorporated in oligonucleotides ODN1 to ODN8 (Table 1), where the bases flanking the modified residue are varied. They were hybridized with different complementary DNA sequences, 
Scheme 1. Synthesis of Furan-Modified 2'-Amido- and 2'-Ureido-uridine Phosphoramidites ${ }^{a}$

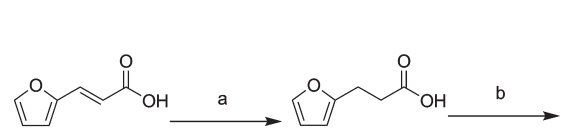<smiles>O=C(Cc1ccco1)Oc1c(F)c(F)c(F)c(F)c1F</smiles>

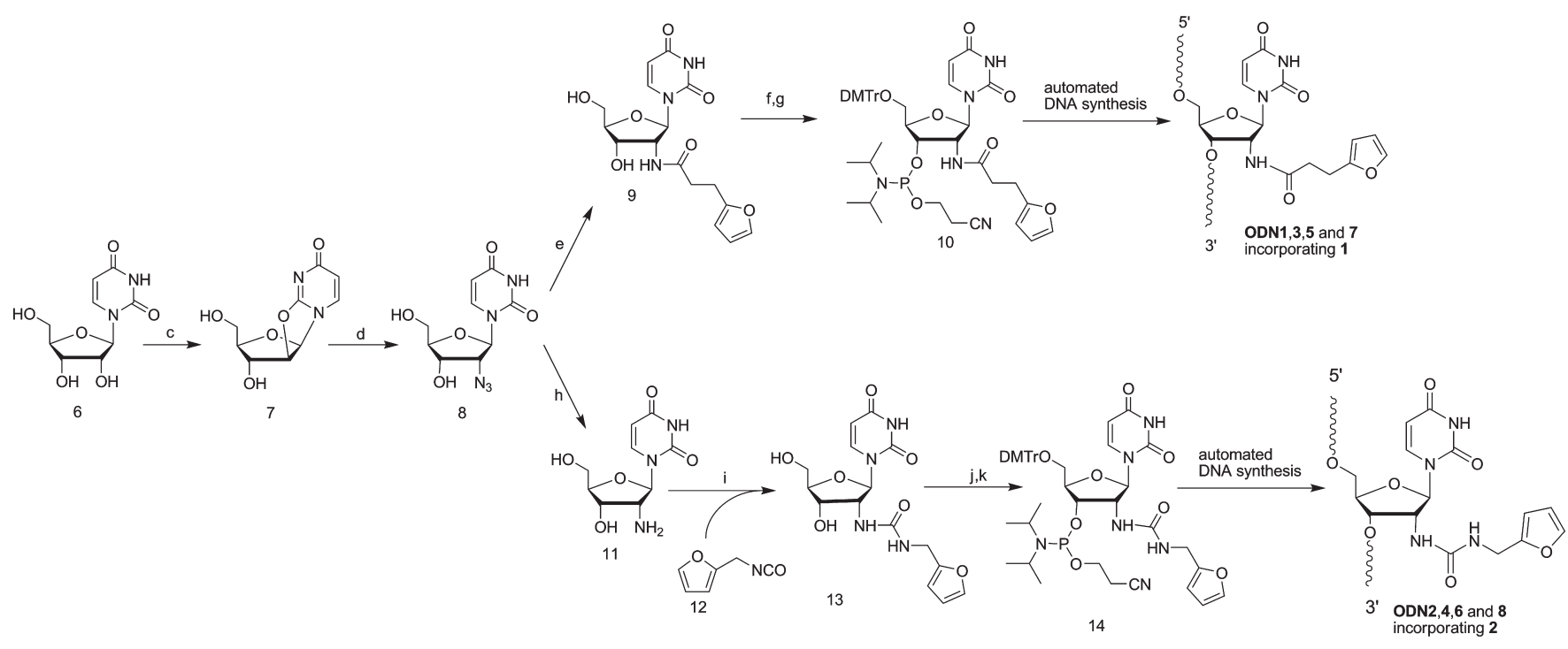

${ }^{a}$ Reagents and conditions: (a) $\mathrm{H}_{2}, \mathrm{Pd} / \mathrm{C}, \mathrm{NH}_{4} \mathrm{OH} / \mathrm{MeOH}, 18 \mathrm{~h}, \mathrm{rt}, 73 \%$; (b) DCC, $\mathrm{C}_{6} \mathrm{~F}_{5} \mathrm{OH}, \mathrm{NEt}_{3} \mathrm{THF}, 15 \mathrm{~h}, \mathrm{rt}, 88 \%$; (c) $(\mathrm{PhO})_{2} \mathrm{CO}, \mathrm{NaHCO}$, DMF, 16 h, $115^{\circ} \mathrm{C}, 74 \%$; (d) LiF, $\mathrm{Me}_{3} \mathrm{SiN}_{3}$, DMF/TMEDA, $63 \mathrm{~h}, 110^{\circ} \mathrm{C}, 72 \%$; (e) i. $\mathrm{PPh}_{3}, 5$, pyridine, 5 h, rt, ii. 13 h, $40{ }^{\circ} \mathrm{C}, 83 \%$; (f) DMTrCI, pyridine, 14 h, rt, 90\%; (g) 2-cyanoethyl- $N, N$-diisopropylchlorophosphine, DIPEA, $2 \mathrm{~h}, 0{ }^{\circ} \mathrm{C}, 76 \%$; (h) $\mathrm{PPh}_{3}, \mathrm{MeOH}^{\mathrm{H}} \mathrm{H}_{2} \mathrm{O}, 3 \mathrm{~h}, 50{ }^{\circ} \mathrm{C}, 89 \%$; (i) 12, DMF, 1 h, 96\%; (j) DMTrCI, pyridine, 17 h, rt, 79\%; (k) 2-cyanoethyl- $N, N$-diisopropylchlorophosphine, DIPEA, 2.5 h, $0{ }^{\circ} \mathrm{C}, 50 \%$.

Scheme 2. Proposed Mechanism of Degradation of the Modified Phosphoramidites in the Presence of DCI

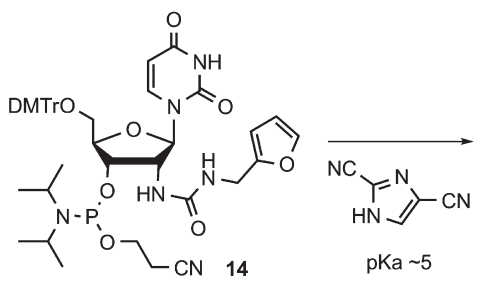

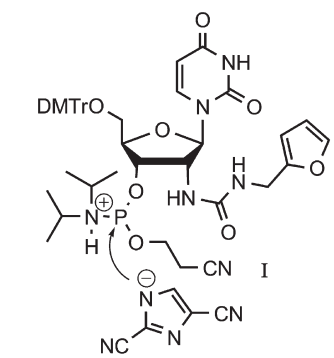

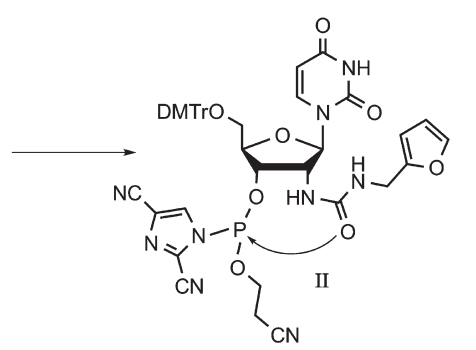<smiles>N#CCCOP1OC2C[C@H](O1)[C@H](n1ccc(=O)[nH]c1=O)OC(NCc1ccco1)=N2</smiles>

varying the base opposite the modification. In this way, 32 duplexes were generated.

Duplex stability determination via UV melting temperatures demonstrated that destabilization of the modified duplexes is observed and ranges from -4.1 to $-20.6{ }^{\circ} \mathrm{C}$ for $2^{\prime}$-amido- and from -3.7 to $-14.1{ }^{\circ} \mathrm{C}$ for $2^{\prime}$-ureido-furan-modified duplexes. Interestingly, it can be noticed that duplexes incorporating 2 opposite A are considerably more stable than those incorporating
Table 1. Modified ODN Sequences and Their Complements ${ }^{a}$

\begin{tabular}{|c|c|}
\hline modified sequence & $\begin{array}{l}\text { complementary } \\
\text { sequence }\end{array}$ \\
\hline \multicolumn{2}{|l|}{ ODN1: } \\
\hline $5^{\prime}$-CTG ACG G1G TGC-3' & ODN9a-d: \\
\hline $\begin{array}{l}\text { ODN2: } \\
\text { 5'-CTG ACG G2G TGC-3' }\end{array}$ & $3^{\prime}$-GAC TGC CNC ACG-5' \\
\hline \multicolumn{2}{|l|}{ ODN3: } \\
\hline $5^{\prime}$-CTG ACG T1T TGC-3' & ODN10a-d: \\
\hline $\begin{array}{l}\text { ODN4: } \\
\text { 5'-CTG ACG T2T TGC-3' }\end{array}$ & $3^{\prime}$-GAC TGC ANA ACG-5' \\
\hline \multicolumn{2}{|l|}{ ODN5: } \\
\hline $5^{\prime}$-CTG ACG C1C TGC-3' & ODN11a-d: \\
\hline $\begin{array}{l}\text { ODN6: } \\
\text { 5'-CTG ACG C2C TGC-3' }\end{array}$ & $3^{\prime}$-GAC TGC GNG ACG-5' \\
\hline \multicolumn{2}{|l|}{ ODN7: } \\
\hline $5^{\prime}$-CTG ACG A1A TGC-3' & ODN12a-d: \\
\hline $\begin{array}{l}\text { ODN8: } \\
\text { 5'-CTG ACG A2A TGC-3' }\end{array}$ & $3^{\prime}$-GAC TGC TNT ACG-5' \\
\hline \multicolumn{2}{|c|}{$\begin{array}{l}{ }^{a} \text { In the modified sequences: } 1,2^{\prime} \text {-amidofuran-modified uridine; } 2,2^{\prime} \text { - } \\
\text { ureidofuran-modified uridine. In the complements: } a, N=A ; b, N=C ; c \text {, } \\
N=G ; d, N=T \text {. }\end{array}$} \\
\hline
\end{tabular}

1 opposite A. The effect is more pronounced in the case of flanking pyrimidines (with ODN4:ODN10a and ODN6:ODN11a 
Chart 1. Melting Temperatures of Modified versus Unmodified Duplexes

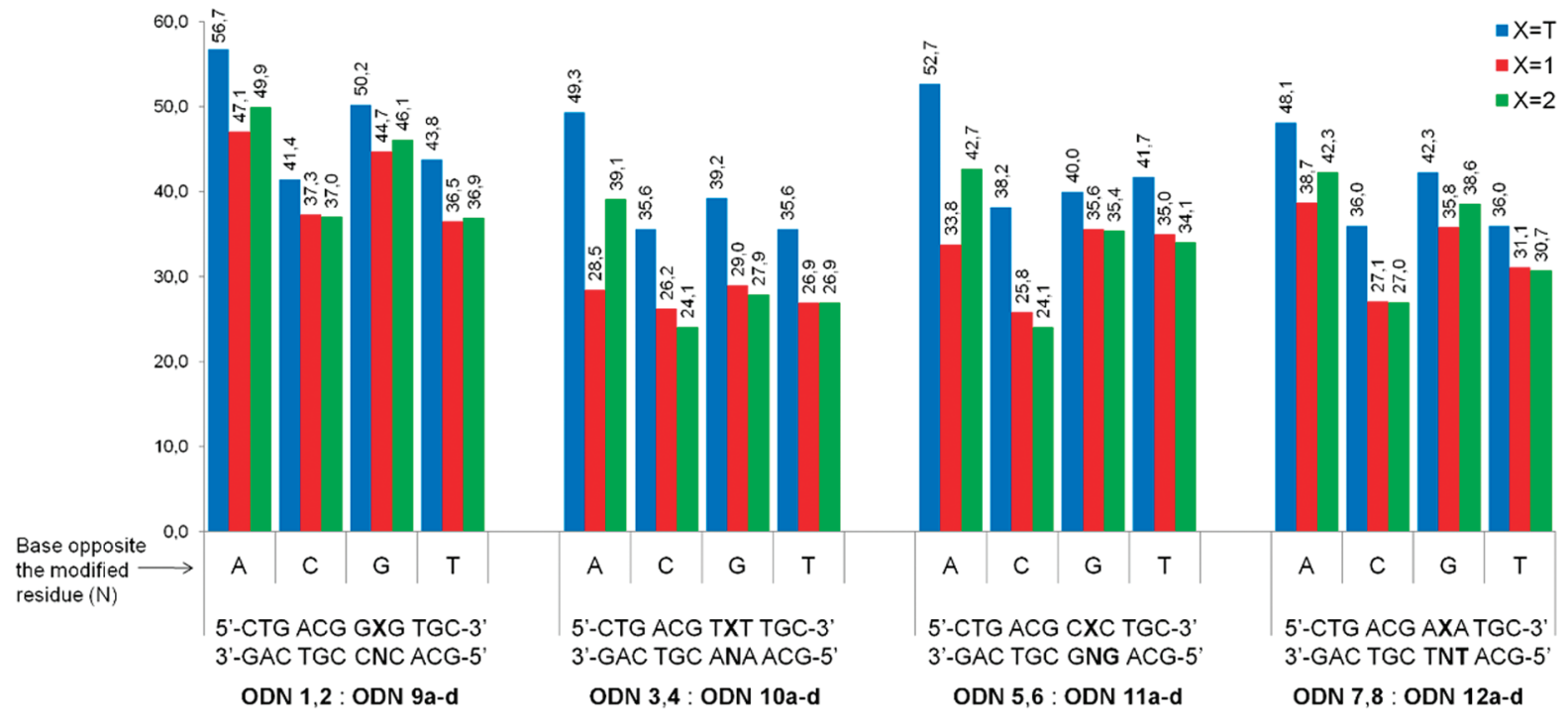

being $9-10{ }^{\circ} \mathrm{C}$ more stable than the corresponding amido analogues) than in the case of flanking purines (with ODN2: ODN9a and ODN8:ODN12a being $3-4{ }^{\circ} \mathrm{C}$ more stable than the corresponding amido analogues) (Chart 1).

Cross-linking experiments were performed by selective furan oxidation using $\mathrm{N}$-bromosuccinimide (NBS). Addition of 4 equiv was necessary to ensure complete conversion of the modified ODN. Reactions were followed by denaturing polyacrylamide gel electrophoresis (PAGE) and RP-HPLC. PAGE experiments show that, in the case of the amido-modified oligonucleotides ODN1, 3, 5, and 7, cross-linking occurs when there is an adenine or cytosine opposite the modified residue (Figure 2, panels I-IV), as evidenced by the appearance of a new, slow-running species.

In all cases, the signal of the modified strand has completely disappeared in the RP-HPLC profile after addition of 4 equiv of NBS. As can be observed in the control chromatograms (Figure 3, left), upon NBS treatment the modified strands are transformed into a mixture of degradation products, as indicated by the formation of a very broad signal with low intensity. In the case of adenosine as complementary base to the $2^{\prime}$-amidofuran-modified uridine, no substantial amount of crosslinked product could be observed (Figure 3A, $\mathrm{N}=\mathrm{A}$ ). As a suitable cross-linking complement is absent, the signal for the unmodified ODN10a is still intact, and a broad smear can be observed for the degradation products of the modified ODN. However, with a cytosine opposite to the modified residue, two new peaks (XL1 and XL2) are formed (Figure 3A, N = C), as can also be observed on PAGE by the appearance of two closely located spots. Further PAGE analysis at elevated temperatures showed the originally formed species cross-linked to A not to be stable. In the case of the $2^{\prime}$-ureido-modified oligonucleotides, we observed complete C-selectivity of the cross-linking reaction (Figure 2, panels $\mathrm{V}-\mathrm{VIII}$ ). In this case, only one main new peak (XL) appears in the RP-HPLC spectrum after addition of 4 equiv of NBS (Figure 3B, $N=C$ ). With ODN6 and ODN8, a small second peak is also formed (see Supporting Information).
Characterization of Cross-Linked Species. The adducts that form between the natural metabolite of furan, cis-2-butenedial, and the nucleobases of DNA are well described in the literature. With $\mathrm{dC}$ showing the highest reactivity, the reaction occurs according to the mechanism depicted in Scheme 3..$^{53-58}$ Initial attack of the exocyclic amine is followed by a cyclative rearrangement, resulting in bicyclic species 17. Through loss of water, further aromatization can take place.

In order to characterize the nature of the covalent bond formed within the duplexes, cross-linking reactions were repeated on a larger scale, and cross-linked ODNs were purified by RP-HPLC and characterized by ESI-MS (see Supporting Information). From these data, the cross-linked nature of the isolated species can be confirmed, and bromination of purine bases (a possible consequence of NBS treatment of oligonucleotides) can be excluded.

The observed molecular weight (MW) of the cross-linked duplexes containing $2^{\prime}$-amido- and the $2^{\prime}$-ureido-furan-modified building blocks is in accord with the general structure of compound 17. The four diastereomers that can be formed can account for the two peaks (each possibly representing two quasienantiomeric structures) observed in RP-HPLC for the $2^{\prime}$-amido-ODN (cf. Figure $3 \mathrm{~A}, \mathrm{~N}=\mathrm{C}$ ). As for the $2^{\prime}$-ureidofuran-ODN, in some cases a smaller second peak was also formed (see Supporting Information), both the main peak and the smaller peak displaying a MW corresponding to general structure 17. Thus, in addition to leading to a higher selectivity, the more rigid $2^{\prime}$-ureido linker also favors the formation of one of the diastereomers.

For a more accurate characterization of the cross-linked species and identification of the nature of the covalent bond formed, enzymatic digestion of cross-linked duplexes, down to the cross-linked dinucleotide, was carried out. In order to unambiguously prove its structure, we independently prepared a cross-linked dinucleoside via chemical synthesis for RP-HPLC coinjection analysis.

Chemical Synthesis of Cross-Linked Dinucleosides. Before performing the cross-linking reaction of nucleoside 9 with cytidine, the free hydroxyl groups of both compounds need to be 


\section{2'-amido-furan-modified ODN}

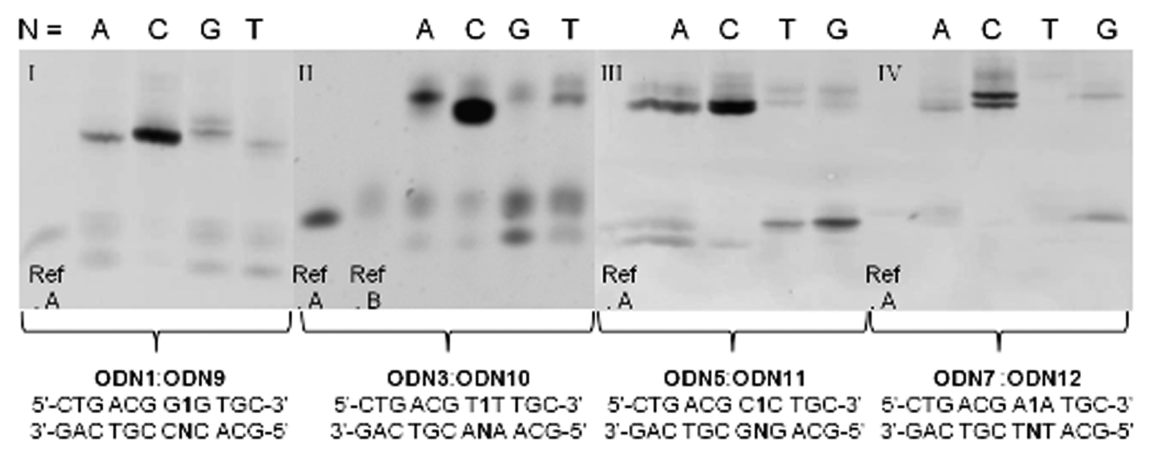

2'-ureido-furan-modified ODN

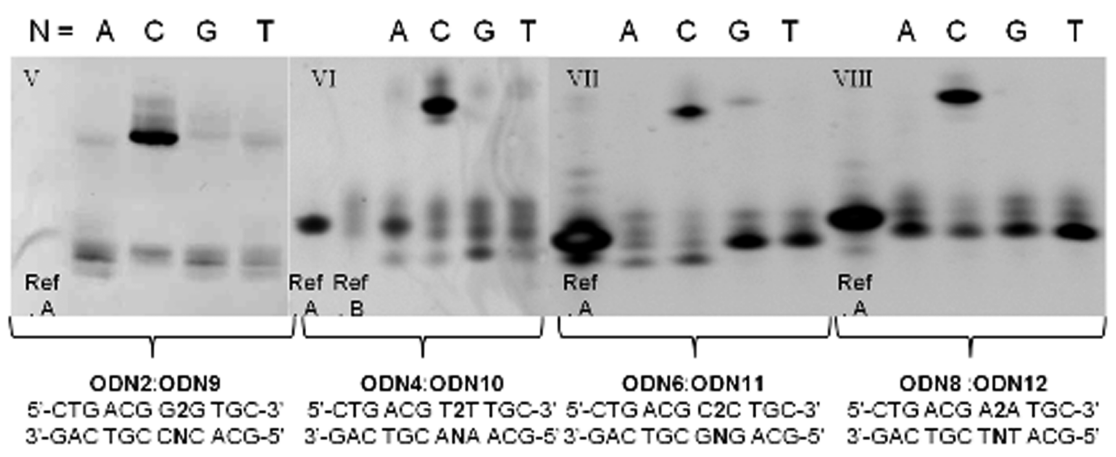

Figure 2. Denaturing PAGE results of the cross-link reaction. Furan-containing ODN1-8 were annealed to complementary ODN9-12, after which NBS was added in portions. ICL formation was analyzed by $20 \%$ denaturing PAGE. Ref A, modified ODN; Ref B, modified ODN +4 equiv of NBS.

acetylated to prevent reaction of the alcohol functionalities with the oxidized furan moiety. Following protection, cross-linking was performed by oxidation of the furan moiety in protected nucleoside 19 with 1.1 equiv of NBS, after which $3^{\prime}, 5^{\prime}$-bis-acetylprotected cytidine 21 was added (Scheme 4). ${ }^{59}$ After straightforward deprotection with methanolic ammonia, the desired crosslinked dinucleoside 23 was obtained in good yield. Dinucleoside 23 is, however, present as an inseparable diastereomeric mixture, rendering NMR characterization complicated. To simplify identification, we attempted to convert dinucleoside 23 to the aromatized nucleoside 24. Heating of dinucleoside 23 in water or acetonitrile led to the formation of unwanted side products. After evaluating several conditions, aromatization in $0.1 \mathrm{M} \mathrm{HCl}_{\mathrm{aq}}$ solution for 9 days was found to give the cleanest conversion to compound 24 (Figure 4). The structure of this compound could be unambiguously confirmed by NMR (see Supporting Information).

Cross-linking of $2^{\prime}$-ureido-furan-modified nucleoside 25 with protected cytidine 21 was attempted under several reaction conditions, but in each case a complex reaction mixture was obtained. The reaction mixture was analyzed in detail by LC-MS, and the main peaks could be assigned to unreacted starting material, overoxidized nucleoside 26, two signals of which the MW corresponds to the mass of cross-linked compound 27, and two signals of which the MW corresponds to the mass of cross-linked, aromatized dinucleoside $\mathbf{2 8}$ (Scheme 5 and Supporting Information).

In contrast to the slow and difficult dehydration of 23 to 24 , aromatization of $\mathbf{2 7}$ to $\mathbf{2 8}$ occurs concurrently with the cross-link formation. Presumably, the extra nitrogen in the $2^{\prime}$-ureido-modified nucleoside can catalyze the dehydration reaction, which could account for the spontaneous aromatization (see Figure 5A).
In addition, this extra nitrogen can activate the keto functionality of the formed oxo-enal species 29 through hydrogen bonding. As a consequence, next to the expected attack of the exocyclic $\mathrm{NH}_{2}$ functionality according to pathway a, attack through pathway $b$ may become possible, allowing formation of two regioisomeric aromatized species, 28 and 31, consistent with the appearance of two signals of identical mass in the ESI-MS spectrum (see Supporting Information).

As illustrated above, when the cross-linking reaction is performed on the $2^{\prime}$-ureido-furan-modified ODN, only one main product with a mass corresponding to cross-linked compound 17 is formed. Most likely, when the nucleoside is incorporated in an ODN duplex, it is forced into a specific conformation that does not allow this H-bond formation, catalyzing these side reactions. Additionally, as only one species is observed in this case on RP-HPLC (cf. Figure 3B, $\mathrm{N}=\mathrm{C}$ ), cross-linking reaction with these $2^{\prime}$-ureido-furan-modified ODNs most likely leads to the preferential formation of one diastereomer. These results indicate that, upon incorporation of this nucleoside in ODN, the linker is forced to adopt a specific conformation in order to fit into the duplex, and this conformational predisposition has a significant influence on the selectivity of the reaction.

Aromatization of the Cross-Linked 2'-Amido-furanModified Duplex. To allow comparison of the chemically synthesized, characterized dinucleotide $\mathbf{2 4}$ with a dinucleotide obtained by enzymatic digestion of the $2^{\prime}$-amido-modified cross-linked duplex, the two diastereomeric cross-linked duplexes (cf. Figure 3A, N = C) should be converted to the aromatized duplex. In the first instance, the cross-linking reaction was performed in a solution buffered at $\mathrm{pH} 5$. However, no different reactivity was observed compared to 


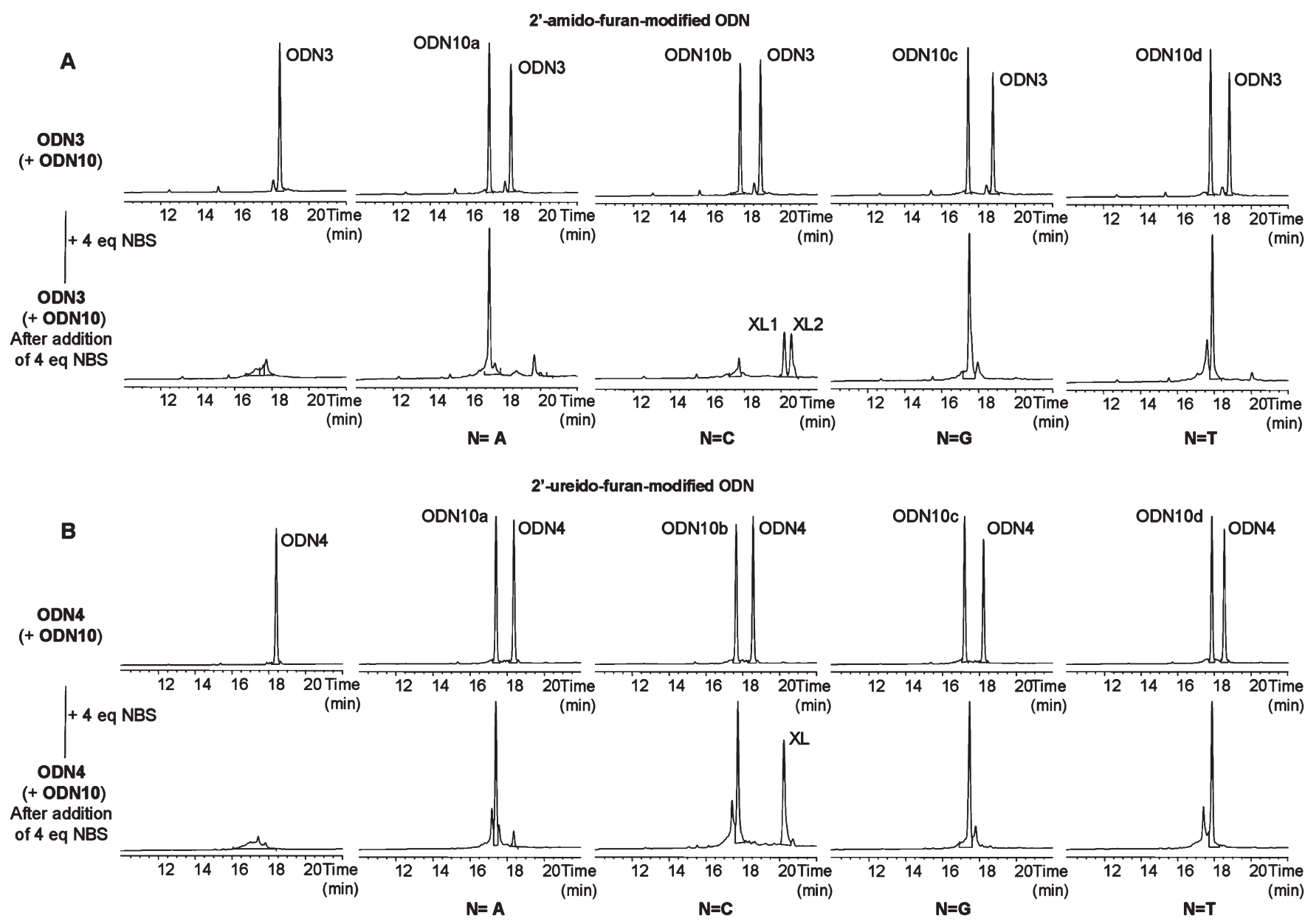

Figure 3. RP-HPLC of the cross-link reaction mixtures with (A) ODN3:ODN10 ( $5^{\prime}$-CTG ACG T1T TGC-3' $: 3^{\prime}$-GAC TGC ANA ACG-5') and (B) ODN4:ODN10 ( $5^{\prime}$-CTG ACG T2T TGC-3' $: 3^{\prime}$-GAC TGC ANA ACG-5 $)$, before and after addition of 4 equiv of NBS. All ODN sequences are mixed in a 1:1 ratio. XL represents the cross-linked product; depending on the cross-linking efficiency, the nonconsumed unmodified strand can still be observed.

Scheme 3. Mechanism of Adduct Formation between $\mathrm{dC}$ and an Oxidized Furan Derivative

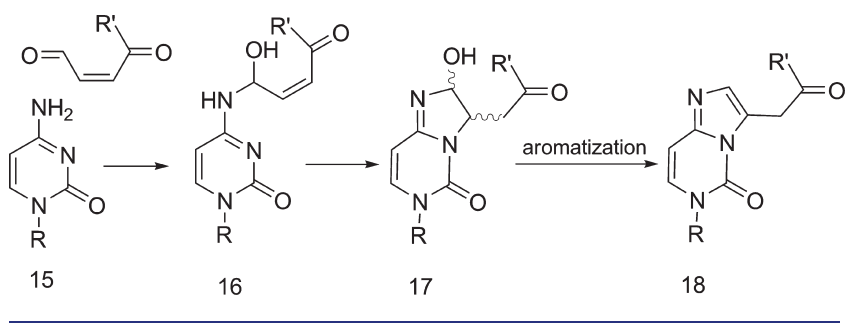

reaction at $\mathrm{pH}$ 7. Since the aromatization reaction can also be induced by heating, the two presumed diastereomeric duplexes were incubated at $50{ }^{\circ} \mathrm{C}$ (Figure 6). The reaction was followed by HPLC, and, depending on the sequence, aromatization was finished after $1-3$ days. The aromatized cross-linked duplex (XLar) was purified by RP-HPLC and analyzed by ESI-MS, which confirmed its aromatized structure (see Supporting Information).

Confirmation of the Cross-Link Structure by Enzymatic Digestion and Coinjection. Enzymatic digestion of the aromatized duplex XLar, obtained after cross-linking ODN3 with ODN10b,

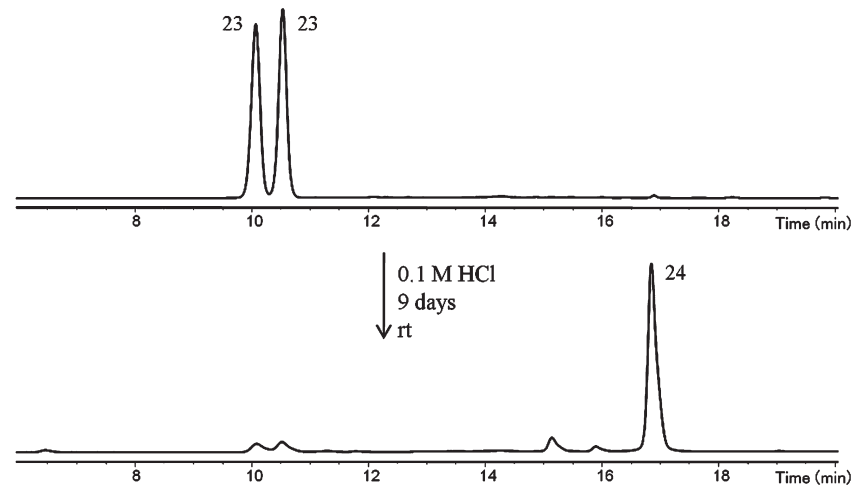

Figure 4. Aromatization of diastereomeric compound 23 as followed by RP-HPLC.

was performed with snake venom phosphodiesterase (SVPD). Unlike exonuclease III, this enzyme was able to surpass the crosslink to produce the cross-linked dinucleotide (see Figure 7). ${ }^{60}$ After removal of the phosphate groups with alkaline phosphatase, the reaction mixture containing the desired dinucleotide can be analyzed by coinjection with cross-linked dinucleoside 24 (Scheme 4), confirming the identity of the cross-link structure (Figure 8). 
Scheme 4. Chemical Synthesis of Cross-Linked Dinucleoside Derived from $2^{\prime}$-Amido-Modified 9 and $\mathrm{dC}^{a}$

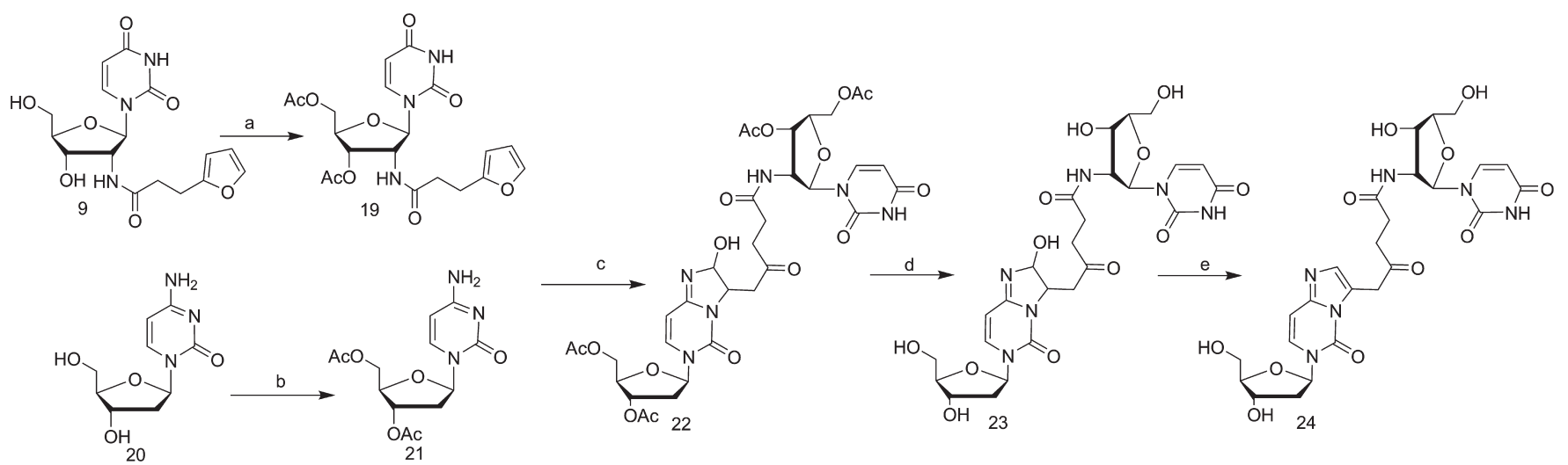

${ }^{a}$ Reagents and conditions: (a) Ac 2 O, DMAP, NEt 3 , ACN, 2 h, rt, 67\%; (b) Ac 2 O, DMAP, NEt ${ }_{3}$, ACN, overnight, rt, 68\%; (c) NBS, pyridine, THF/ acetone $/ \mathrm{H}_{2} \mathrm{O} 5 / 4 / 2$, overnight, rt; (d) $\mathrm{NH}_{3} / \mathrm{MeOH}$, overnight, rt, $80 \%$ (over two steps); (e) $0.1 \mathrm{M} \mathrm{HCl}, 9$ days, rt, quantitative.

Scheme 5. Chemical Synthesis of the Putative Cross-Linked Dinucleoside Derived from $2^{\prime}$-Ureido-Modified 13 and $\mathrm{dC}^{a}$

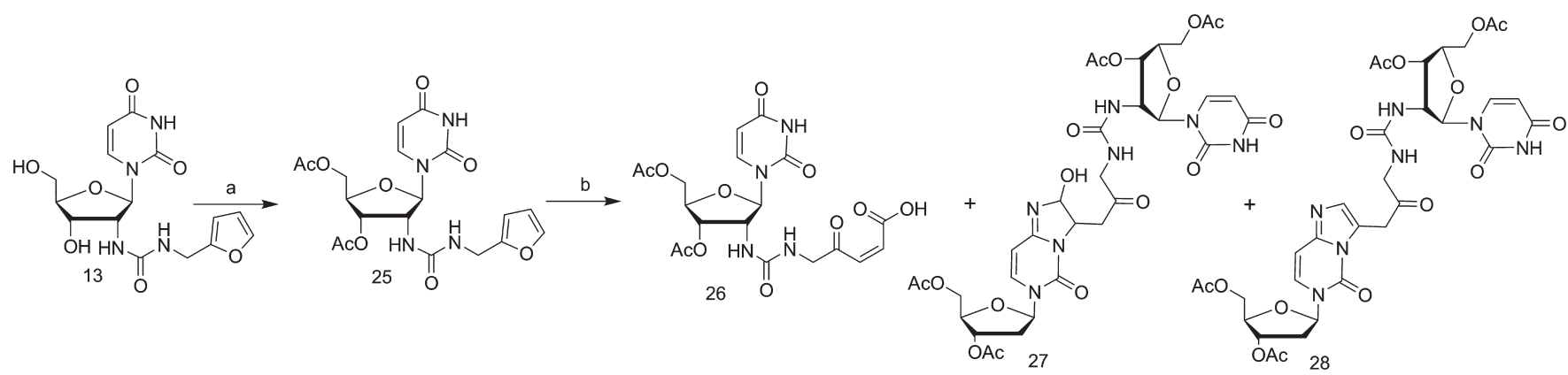

${ }^{a}$ Reagents and conditions: (a) $\mathrm{Ac}_{2} \mathrm{O}, \mathrm{DMAP}, \mathrm{NEt}_{3}, \mathrm{ACN}, 1 \mathrm{~h}, \mathrm{rt}, 67 \%$; (b) 21, NBS, pyridine, THF/acetone/ $\mathrm{H}_{2} \mathrm{O}$ 5/4/2, overnight, rt.<smiles>[R]NC(=O)NCC(=O)Cc1cnc2ccn([R])c(=O)n12</smiles>

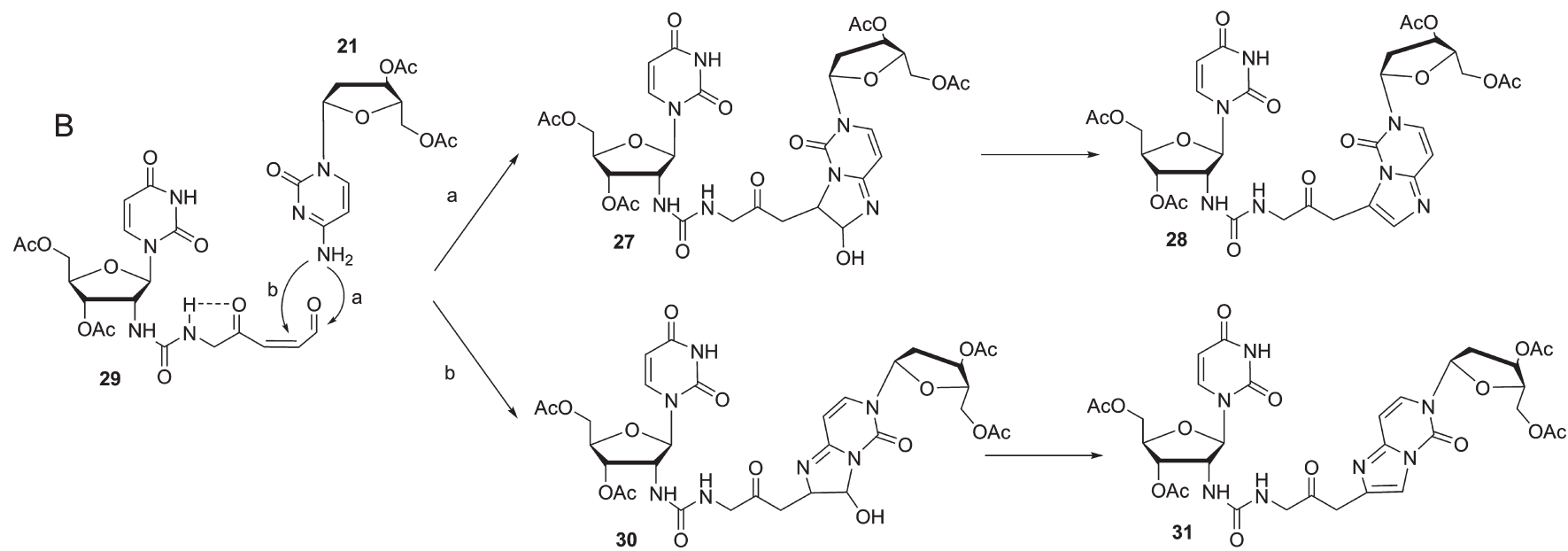

Figure 5. (A) Catalysis of the spontaneous aromatization reaction through intramolecular H-bonding. (B) Hydrogen bonding in the oxidized nucleoside allows alternative attack according to pathway $\mathrm{b}$. 


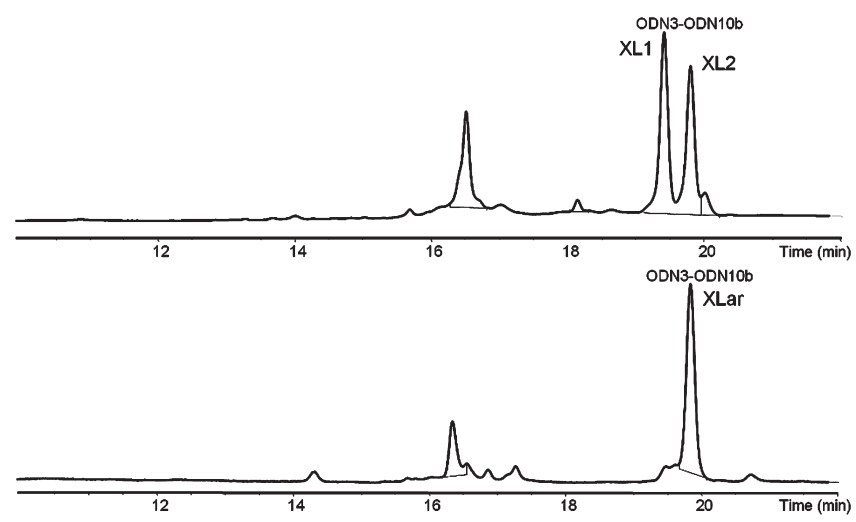

Figure 6. Conversion of the diastereomeric cross-linked duplexes (XL1 and XL2) from ODN3-ODN10b to the aromatized duplex (XLar) by prolonged heating at $50{ }^{\circ} \mathrm{C}$.

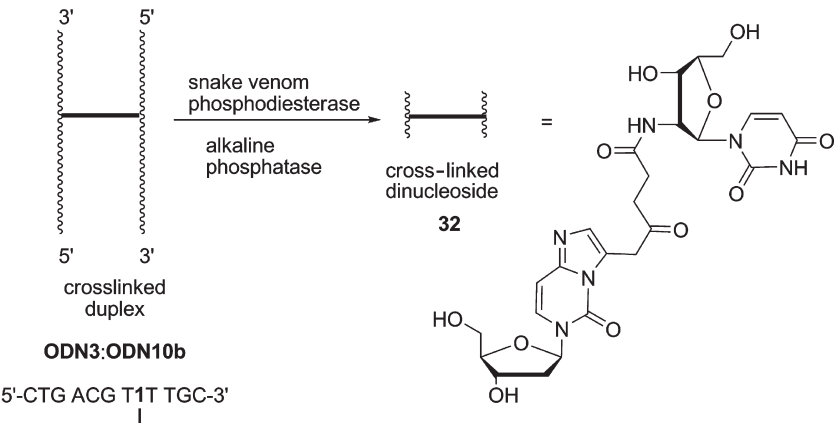

3'-GAC TGC ACA ACG-5'

Figure 7. Enzymatic degradation of the cross-linked duplex.

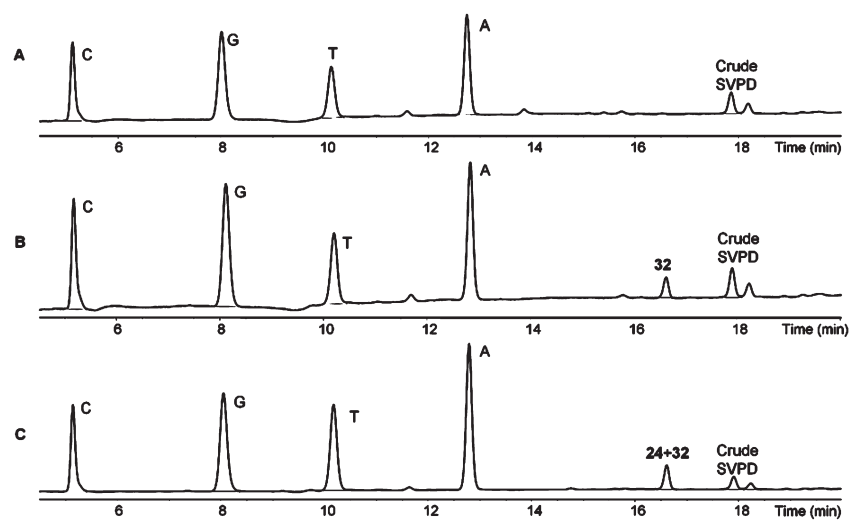

Figure 8. Coinjection experiments. (A) Reference sample: injection of A, C, T, and G in the presence of crude SVPD. (B) Reaction mixture after overnight reaction with SVPD and $1 \mathrm{~h}$ reaction with alkaline phosphatase. (C) Coinjection of the digestion mixture containing 32 and synthesized dinucleoside 24 .

Cross-Linking Yield and Stability. The yield of the crosslinking reactions was calculated by determination of the HPLC peak area. Additionally, isolated yields were determined in the case of XLar of the $2^{\prime}$-amido-furan-modified duplexes and XL of the $2^{\prime}$-ureido-furan-modified duplexes (see Table 2 ).

As is obvious from Table 2, average yields of $20 \%$ are consistently obtained, underscoring the efficiency of the furan
Table 2. Yields of Cross-Linked Duplexes ${ }^{a}$

\begin{tabular}{|c|c|c|c|c|c|}
\hline \multirow[b]{2}{*}{ modified sequence } & \multicolumn{2}{|c|}{$\begin{array}{l}\text { yield based on } \\
\text { HPLC (\%) }\end{array}$} & \multicolumn{3}{|c|}{$\begin{array}{c}\text { isolated } \\
\text { yield }(\%)\end{array}$} \\
\hline & $\mathrm{XL1}$ & $\mathrm{XL} 2$ & $\mathrm{XL1}$ & $\mathrm{XL2}$ & XLar \\
\hline $\begin{array}{l}\text { ODN1: } \\
\text { 5'-CTG ACG G1G TGC-3' }\end{array}$ & 33 & 27 & 12 & 12 & 32 \\
\hline $\begin{array}{l}\text { ODN2 } \\
5^{\prime}-\mathrm{CTG} \text { ACG G2G TGC-3' }\end{array}$ & 55 & & 21 & & \\
\hline $\begin{array}{l}\text { ODN3: } \\
\text { 5'-CTG ACG T1T TGC-3' }\end{array}$ & 30 & 25 & 28 & 25 & 27 \\
\hline $\begin{array}{l}\text { ODN4: } \\
\quad 5^{\prime} \text {-CTG ACG T2T TGC-3' }\end{array}$ & 37 & & 16 & & \\
\hline $\begin{array}{l}\text { ODN5: } \\
\text { 5'-CTG ACG C1C TGC-3' }\end{array}$ & 29 & 31 & 18 & 17 & 26 \\
\hline $\begin{array}{l}\text { ODN6: } \\
\text { 5'-CTG ACG C2C TGC-3' }\end{array}$ & 26 & 10 & 20 & 8 & \\
\hline $\begin{array}{l}\text { ODN7: } \\
\text { 5'-CTG ACG A1A TGC-3' }\end{array}$ & 41 & 23 & 19 & 7 & 18 \\
\hline $\begin{array}{l}\text { ODN8: } \\
\text { 5'-CTG ACG A2A TGC-3' }\end{array}$ & 39 & 7 & 29 & 5 & \\
\hline $\begin{array}{l}\text { Complementary sequences } \\
\text { pposing the modified build } \\
\text { IPLC purified material. }\end{array}$ & all & $\begin{array}{l}\text { fea } \\
\text { ola }\end{array}$ & $\mathrm{C}$ & the & sid \\
\hline
\end{tabular}

oxidation methodology for the production of considerable quantities of site-specifically cross-linked duplexes.

Additionally, the stability of the formed cross-linked species (XLar in the case of $2^{\prime}$-amido-furan-modified duplexes and XL in the case of $2^{\prime}$-ureido-furan-modified duplexes) was assessed by measurement of melting temperatures. In all cases, the melting temperature was greatly increased by introduction of the crosslink in the duplex $\left(\Delta T_{\mathrm{m}}=+38\right.$ to $+58.3^{\circ} \mathrm{C}$, see Supporting Information).

\section{CONCLUSION}

Furan-modified nucleosides were synthesized for incorporation into ODNs, where the furan unit is attached to the $2^{\prime}$-position of the sugar through an amide or ureide linker. Conditions for incorporation into ODNs were optimized, and the desired ODNs were obtained pure and in good yield by simple SEP-PAK purification. Cross-linking reactions can be performed by converting the stable furan functionality into a reactive dicarbonyl moiety by selective oxidation with NBS. The reaction proceeds instantaneously and in good yield, especially considering that, in contrast to most literature precedents, reaction mixtures have been RP-HPLC purified and cross-linked duplexes have been isolated and quantified. The selectivity of the cross-linking reactions was determined by varying the bases flanking and opposite the modified residue. Cross-linking does not appear to be influenced by the sequence in which the modified uridine was incorporated (bases flanking the modification). The $2^{\prime}$-amido-modified ODN showed cross-linking selectivity for adenine and cytosine bases. As cross-links to adenine were not stable at elevated temperatures, $\mathrm{C}$-selectivity can be obtained in this case by simple heating. The $2^{\prime}$-ureido-modified ODN showed a clear selectivity for cross-link formation with cytosine. 
Furthermore, we unambiguously proved the structure of the formed cross-link species by coinjection of the enzymatic digestion reaction mixture with the synthesized dinucleoside. Isolated yields are such that substantial amounts of site-specifically crosslinked duplexes can be obtained.

The current study illustrates the important influence of small structural changes on cross-link selectivity. The 2 '-ureidofuran-modified uridine described here is an ideal complement to our toolbox of furan-modified building blocks, featuring an unprecedented cross-link selectivity.

\section{EXPERIMENTAL SECTION}

Materials and Methods for Chemical Synthesis. All solvents and chemical reagents were purchased from Sigma-Aldrich. ${ }^{1} \mathrm{H}$ and ${ }^{13} \mathrm{C}$ NMR spectra were recorded on a Bruker Avance 300 or a Bruker DRX 500 spectrometer operating at room temperature. Chemical shifts are reported in parts per million $(\delta)$ relative to the residual solvent peak. Multiplicities are reported as singlet (s), doublet (d), doublet of doublets $(\mathrm{dd})$, triplet $(\mathrm{t})$, or multiplet $(\mathrm{m})$. Purities of small compounds were checked by RP-HPLC-MS or by RP-HPLC. For RP-HPLC-MS, an Agilent 1100 series LC-MS system was used, equipped with a Phenomenex Luna C18 column $\left(250 \times 4.6 \mathrm{~mm}, 5 \mu \mathrm{m}\right.$, at $\left.35^{\circ} \mathrm{C}\right)$. The used solvent system was $5 \mathrm{mM} \mathrm{NH}_{4} \mathrm{OAc}$ in water (A) and $\mathrm{MeCN}$ (B). The gradient went from 0 to $100 \%$ B in 15 min. For RP-HPLC, an Agilent 1100 system was used, equipped with a Phenomenex Luna C18 column $(250 \times$ $4.6 \mathrm{~mm}, 5 \mu \mathrm{m}$, at $50{ }^{\circ} \mathrm{C}$ ), with $0.1 \mathrm{M}$ TEAA (containing $8 \% \mathrm{MeOH}$ ) and $\mathrm{MeOH}$ as mobile phase (linear gradient: $0-30 \% \mathrm{MeOH}$ in $15 \mathrm{~min}$, $30-100 \% \mathrm{MeOH}$ in $3 \mathrm{~min}$ ). HRMS spectra were recorded on a Micromass Q-Tof 2 instrument (Z-spray electrospray quadrupole/orthogonal acceleration time-of-flight tandem MSWaters CapLC with PDA).

3-(Furan-2-yl)propanoic Acid, 4. Furan-2-acrylic acid (0.5 g, 3.62 $\mathrm{mmol}$ ) was dissolved in $\mathrm{MeOH}(25 \mathrm{~mL})$. A concentrated $\mathrm{NH}_{4} \mathrm{OH}$ solution $(270 \mu \mathrm{L})$ was added, followed by $\mathrm{Pd} / \mathrm{C}(10 \%, 8.5 \mathrm{mg})$. Hydrogenation was performed under a slight positive hydrogen pressure for $18 \mathrm{~h}$. Pd/C was removed by filtration through Celite. The product was concentrated, and the resulting oil was dissolved in $5 \mathrm{~mL}$ of $\mathrm{H}_{2} \mathrm{O}$. The $\mathrm{pH}$ of this solution was adjusted to 2 with $2 \mathrm{~N} \mathrm{HCl}$, resulting in a white precipitate. The desired product was extracted using ethyl acetate $(4 \times 25 \mathrm{~mL})$. The combined organic layers were dried on $\mathrm{MgSO}_{4}$ and concentrated. The residue was purified by flash chromatography using isooctane:EtOAc 4:1. The desired product was obtained as white needles $(0.369 \mathrm{~g}, 2.63 \mathrm{mmol})$ in $73 \%$ yield. See ref 61 for analytical data.

Pentafluorophenyl-3-(2-furyl) Propanoate, 5. Solid DCC (0.161 g, $0.780 \mathrm{mmol}$ ) was added in portions over a period of $15 \mathrm{~min}$ to a solution of $4(0.101 \mathrm{~g}, 0.724 \mathrm{mmol})$ with pentafluorophenol $(0.146 \mathrm{~g}, 0.795$ $\mathrm{mmol})$ and anhydrous TEA $(0.11 \mathrm{~mL})$ in anhydrous THF $(1.0 \mathrm{~mL})$ under an argon atmosphere at $0{ }^{\circ} \mathrm{C}$. After overnight reaction at room temperature, a white precipitate was formed. Following filtration of the residue, the filtrate was concentrated and purified by flash chromatography using isooctane:ethyl acetate $95: 5$. The product was obtained as white needles $(0.195 \mathrm{~g}, 0.64 \mathrm{mmol})$ in $88 \%$ yield. $R_{f}=0.75$ (isooctane: EtOAc 6:4). ${ }^{1} \mathrm{H}$ NMR (500 MHz, $\left.\mathrm{CDCl}_{3}\right): \delta 7.34(\mathrm{~m}, 1 \mathrm{H}), 6.31(\mathrm{~m}$, $1 \mathrm{H}), 6.11(\mathrm{~m}, 1 \mathrm{H}), 3.12(\mathrm{t}, J=7.4 \mathrm{~Hz}, 2 \mathrm{H}), 3.03(\mathrm{t}, J=7.4 \mathrm{~Hz}, 2 \mathrm{H}) .{ }^{13} \mathrm{C}$ NMR ( $\left.\mathrm{CDCl}_{3}, 125 \mathrm{MHz}\right): \delta 168.5,152.8,142.1,141.6,140.6,140.2$, 138.9, 138.5, 136.9, 110.3, 105.9, 31.9, 23.3. ESI-MS: calcd for $\mathrm{C}_{13} \mathrm{H}_{7^{-}}$ $\mathrm{F}_{5} \mathrm{O}_{3}, 306.0$; found, $329.2[\mathrm{M}+\mathrm{Na}]^{+}$. Anal. Calcd for $\mathrm{C}_{13} \mathrm{H}_{7} \mathrm{~F}_{5} \mathrm{O}_{3}: \mathrm{C}$, 51.00; H, 2.30. Found: C, 50.76; H, 2.44.

2'-Deoxy-2'-[3-(2-furyl)propanamido)]uridine, 9. Nucleoside 8 $(0.401 \mathrm{~g}, 1.49 \mathrm{mmol})$ was added to a mixture of activated ester 5 $(0.455 \mathrm{~g}, 1.49 \mathrm{mmol})$ and triphenylphosphine $(0.428 \mathrm{~g}, 1.63 \mathrm{mmol})$ in pyridine $(15 \mathrm{~mL})$. After $4 \mathrm{~h}$, the starting nucleoside was completely consumed, and the reaction mixture was further stirred overnight at $40^{\circ} \mathrm{C}$. The reaction was quenched with $\mathrm{H}_{2} \mathrm{O}(0.4 \mathrm{~mL})$ and concentrated in vacuo. The majority of the formed triphenylphosphine oxide could easily be separated from the reaction mixture by trituration in toluene $(15 \mathrm{~mL})$. The resulting brownish foam was concentrated onto silica and purified by flash chromatography with DCM:MeOH 94:6. The desired product was obtained as a white foam $(0.451 \mathrm{~g}, 1.23 \mathrm{mmol})$ in $83 \%$ yield. $R_{f}$ $=0.25$ (DCM:MeOH 9:1). ${ }^{1} \mathrm{H}$ NMR (300 MHz, MeOD): 7.95 (d, $J=8.1$ $\mathrm{Hz}, 1 \mathrm{H}), 7.26(\mathrm{dd}, J=1.9$ and $0.8 \mathrm{~Hz}, 1 \mathrm{H}), 6.21(\mathrm{dd}, J=1.9$ and $3.1 \mathrm{~Hz}$, $1 \mathrm{H}), 6.01(\mathrm{~d}, J=8.5 \mathrm{~Hz}, 1 \mathrm{H}), 5.95(\mathrm{dd}, J=3.1$ and $0.8 \mathrm{~Hz}, 1 \mathrm{H}), 5.69$ $(\mathrm{d}, J=8.1 \mathrm{~Hz}, 1 \mathrm{H}), 4.59(\mathrm{dd}, J=8.5$ and $5.6 \mathrm{~Hz}, 1 \mathrm{H}), 4.18(\mathrm{dd}, J=5.6$ and $1.3 \mathrm{~Hz}, 1 \mathrm{H}), 4.02(\mathrm{~m}, 1 \mathrm{H}), 3.72(\mathrm{~m}, 2 \mathrm{H}), 2.87(\mathrm{~m}, 2 \mathrm{H}), 2.54(\mathrm{~m}, 2 \mathrm{H})$. ${ }^{13} \mathrm{C}$ NMR (75 MHz, MeOD): $\delta 177.8,168.6,158.2,155.3,145.1$, 144.9, 113.7, 108.8, 105.8, 91.2, 90.5, 74.8, 65.8, 59.3, 37.6, 27.4. ESI-MS: calcd for $\mathrm{C}_{16} \mathrm{H}_{19} \mathrm{~N}_{3} \mathrm{O}_{7}, 365.1$; found, $366.1[\mathrm{M}+\mathrm{H}]^{+}$. Anal. Calcd for $\mathrm{C}_{16} \mathrm{H}_{19} \mathrm{~N}_{3} \mathrm{O}_{7}$ : C, 52.60; H, 5.24; N, 11.50. Found: C, 52.06; H, 5.45; N, 11.92 .

2'-Deoxy-2'-[3-(2-furyl)propanamido)]-5'-O-(4,4'-dimethoxytrityl)uridine 3'-(2-Cyanoethyl N,N-Diisopropylphosphoramidite), 10. Compound $9(0.199 \mathrm{~g}, 0.55 \mathrm{mmol})$ was dried by co-evaporation with pyridine $(3 \times 5 \mathrm{~mL})$ and then dissolved in $5.5 \mathrm{~mL}$ of pyridine and cooled to $0{ }^{\circ} \mathrm{C}$. $\mathrm{DMTrCl}(0.264 \mathrm{~g}, 0.78 \mathrm{mmol})$ was added, and the reaction was stirred overnight at room temperature. The reaction was checked by TLC and cooled to $0^{\circ} \mathrm{C}$, and then another portion of $\mathrm{DMTrCl}(0.186 \mathrm{~g}, 0.55 \mathrm{mmol})$ was added. The reaction was allowed to stir at room temperature for $24 \mathrm{~h}$, after which the reaction was cooled to $0{ }^{\circ} \mathrm{C}$ and quenched with $\mathrm{MeOH}$ $(0.25 \mathrm{~mL})$. The reaction mixture was diluted with EtOAc $(20 \mathrm{~mL})$ and washed with water $(15 \mathrm{~mL}), \mathrm{NaHCO}_{3 \text { aq, sat }}(15 \mathrm{~mL})$, and $\mathrm{NaCl}_{\text {aq,sat }}$ $(15 \mathrm{~mL})$. The combined aqueous phases were again extracted with 45 $\mathrm{mL}$ of EtOAc, after which the organic phases were combined and dried on $\mathrm{Na}_{2} \mathrm{SO}_{4}$. The filtrate was concentrated by rotary evaporation and purified by flash chromatography with isooctane:EtOAc:TEA 80:19:1. The product was obtained as an off-white foam $(0.3295 \mathrm{~g}, 0.49 \mathrm{mmol})$ in $89 \%$ yield. $R_{f}=$ 0.55 (DCM:MeOH 10:1). ${ }^{1} \mathrm{H}$ NMR (MeOD, $300 \mathrm{MHz}$ ): 7.83 (d, $J=8.1$ $\mathrm{Hz}, 1 \mathrm{H}), 7.23-7.44(\mathrm{~m}, 10 \mathrm{H}), 6.90(\mathrm{~d}, J=8.7 \mathrm{~Hz}, 4 \mathrm{H}), 6.25(\mathrm{~m}, 1 \mathrm{H}), 6.07$ $(\mathrm{d}, J=8.5 \mathrm{~Hz}, 1 \mathrm{H}), 6.01(\mathrm{~d}, J=3.0 \mathrm{~Hz}, 1 \mathrm{H}), 5.29(\mathrm{~d}, J=8.1 \mathrm{~Hz}, 1 \mathrm{H}), 4.88$ $(\mathrm{m}, 1 \mathrm{H}), 4.33(\mathrm{~d}, J=5.3 \mathrm{~Hz}, 1 \mathrm{H}), 4.11(\mathrm{~m}, 1 \mathrm{H}), 3.78(\mathrm{~s}, 6 \mathrm{H}), 3.42(\mathrm{~m}, 2 \mathrm{H})$, $2.94(\mathrm{~m}, 2 \mathrm{H}), 2.60(\mathrm{~m}, 2 \mathrm{H}) .{ }^{13} \mathrm{C}$ NMR (75 MHz, MeOD): 175.5, 166.1, 160.4, 155.7, 152.7, 145.8, 142.4, 136.9, 136.6, 131.4, 129.5, 129.0, 128.1, 114.3, 111.2, 106.3, 103.0, 88.5, 87.5, 87.3, 72.4, 65.1, 57.0, 55.8, 35.2, 25.0. ESI-MS: calcd for $\mathrm{C}_{37} \mathrm{H}_{37} \mathrm{~N}_{3} \mathrm{O}_{9}, 667.3$; found, 303.4 [DMTr $]^{+}, 684.6$ $\left[\mathrm{M}+\mathrm{NH}_{4}\right]^{+}$. Anal. Calcd for $\mathrm{C}_{37} \mathrm{H}_{37} \mathrm{~N}_{3} \mathrm{O}_{9}: \mathrm{C}, 66.56 ; \mathrm{H}, 5.59 ; \mathrm{N}, 6.29$. Found: C, 66.66; H, 5.69; N, 6.62.

The DMTr-protected nucleoside $(0.1643 \mathrm{~g}, 0.25 \mathrm{mmol})$ was evaporated twice with dry toluene $(2 \times 1 \mathrm{~mL})$ and further dried in vacuo. The product was dissolved in DCM $(2.5 \mathrm{~mL})$ and cooled in an ice bath. DIPEA ( $132 \mu \mathrm{L}, 0.74 \mathrm{mmol})$ was added, followed by the addition of 2-cyanoethyl $N, N$-diisopropylchlorophosphoramidite $(82 \mu \mathrm{L}, 0.37 \mathrm{mmol})$. The reaction mixture was stirred for $1 \mathrm{~h}$ at $0{ }^{\circ} \mathrm{C}$ and then quenched with $\mathrm{MeOH}(0.2 \mathrm{~mL})$. The reaction mixture was diluted with EtOAc $(40 \mathrm{~mL})$, washed once with a saturated $\mathrm{NaHCO}_{3}$ aq solution and three times with saturated $\mathrm{NaCl}_{\mathrm{aq}}(3 \times 40 \mathrm{~mL})$, dried on $\mathrm{Na}_{2} \mathrm{SO}_{4}$, filtered, and concentrated under vacuum. The product was further purified by flash chromatography with EtOAc:isooctane:TEA 60:39:1, resulting in an off-white foam $(0.1631 \mathrm{~g}, 0.19 \mathrm{mmol})$ in $76 \%$ yield. $R_{f}=$ 0.53, 0.57 (isooctane: EtOAc 8:2). The ${ }^{1} \mathrm{H}$ NMR was complex and showed the presence of two diastereomers. ${ }^{31} \mathrm{P}$ NMR $\left(\mathrm{CDCl}_{3}, 121\right.$ $\mathrm{MHz}): \delta$ 151.15, 149.45. ESI-MS: calcd for $\mathrm{C}_{46} \mathrm{H}_{54} \mathrm{~N}_{5} \mathrm{O}_{10} \mathrm{P}, 867.4$; found, $303.3[\mathrm{DMTr}]^{+}, 867.1[\mathrm{M}+\mathrm{H}]^{+}$.

2'-Amino-2'-deoxyuridine, 11. Triphenylphosphine (0.434 g, $1.65 \mathrm{mmol})$ was added to a solution of nucleoside $8(0.406 \mathrm{~g}, 1.51 \mathrm{mmol})$ in $\mathrm{MeOH}: \mathrm{H}_{2} \mathrm{O}$ 9:1 $(16.5 \mathrm{~mL})$. The reaction mixture was stirred for $3 \mathrm{~h}$ at $50{ }^{\circ} \mathrm{C}$ and then concentrated by rotary evaporation. After recrystallization in toluene, the product was obtained as a yellowish powder $(0.3269 \mathrm{~g}, 1.34 \mathrm{mmol})$ in $89 \%$ yield. See ref 62 for analytical data. 
2'-Deoxy-2'-[3-(2-furyl)-2-azapropanamido)]uridine, 13. Compound $11(0.200 \mathrm{~g}, 0.82 \mathrm{mmol})$ was dissolved in dry DMF $(8.2 \mathrm{~mL})$ and cooled in an ice bath. Furfurylisocyanate $12(100 \mu \mathrm{L}, 0.90 \mathrm{mmol})$ was added dropwise, and the reaction was allowed to stir for $1 \mathrm{~h}$. The reaction was quenched with methanol and concentrated under vacuum. After flash chromatography with DCM:MeOH 95:5, the product was obtained as an off-white foam $(0.290 \mathrm{~g}, 0.79 \mathrm{mmol})$ in $96 \%$ yield. $R_{f}=0.24$ (DCM:MeOH 9:1). ${ }^{1} \mathrm{H}$ NMR (MeOD, $\left.300 \mathrm{MHz}\right): \delta 7.99(\mathrm{~d}, J=8.1 \mathrm{~Hz}, 1 \mathrm{H}), 7.37(\mathrm{~d}, J=$ $1.5 \mathrm{~Hz}, 1 \mathrm{H}), 3.31(\mathrm{~m}, 1 \mathrm{H}), 6.17(\mathrm{~d}, J=3.2 \mathrm{~Hz}, 1 \mathrm{H}), 5.98(\mathrm{~d}, J=8.5 \mathrm{~Hz}, 1 \mathrm{H})$, $5.73(\mathrm{~d}, J=8.1 \mathrm{~Hz}, 1 \mathrm{H}), 4.46(\mathrm{dd}, J=8.3$ and $5.7 \mathrm{~Hz}, 1 \mathrm{H}), 4.22(\mathrm{~s}, 2 \mathrm{H}), 4.20$ (m, 1H), $4.02(\mathrm{~m}, 1 \mathrm{H}), 3.74(\mathrm{~m}, 2 \mathrm{H}) .{ }^{13} \mathrm{C} \mathrm{NMR}$ (MeOD, $\left.75 \mathrm{MHz}\right): \delta$ 166.1, 160.0, 154.2, 152.8, 143.1, 142.8, 111.3, 107.4, 103.2, 88.6, 88.5, 72.3, 63.3, 57.4, 37.9. ESI-MS: calcd for $\mathrm{C}_{15} \mathrm{H}_{18} \mathrm{~N}_{4} \mathrm{O}_{7}, 366.1$; found, $367.1[\mathrm{M}+\mathrm{H}]^{+}, 389.4[\mathrm{M}+\mathrm{Na}]^{+}$. HRMS (+ESI): calcd for $\mathrm{C}_{15} \mathrm{H}_{19} \mathrm{~N}_{4} \mathrm{O}_{7}\left(\mathrm{M}+\mathrm{H}^{+}\right)$, 367.1248; found, 367.1259; calcd for $\mathrm{C}_{15} \mathrm{H}_{18} \mathrm{~N}_{4} \mathrm{O}_{7}$ $\mathrm{Na}\left(\mathrm{M}+\mathrm{Na}^{+}\right)$, 389.1067; found, 389.1067; calcd for $\mathrm{C}_{15} \mathrm{H}_{18} \mathrm{~N}_{4} \mathrm{O}_{7} \mathrm{~K}$ $\left(\mathrm{M}+\mathrm{K}^{+}\right)$, 405.0807; found, 405.0804 .

2'-Deoxy-2'-[3-(2-furyl)-2-azapropanamido)]-5'-O-(4,4'-dimethoxytrityl)uridine 3'-(2-Cyanoethyl N,N-Diisopropylphosphoramidite), 14. Compound 12 (0.076 g, $0.207 \mathrm{mmol})$ was co-evaporated three times with pyridine $(3 \times 1 \mathrm{~mL})$ and then dissolved in pyridine $(2 \mathrm{~mL})$ and cooled to $0{ }^{\circ} \mathrm{C}$. DMTrCl $(0.0990 \mathrm{~g}, 0.29 \mathrm{mmol})$ was added, and the reaction was stirred overnight at room temperature. The reaction was checked by TLC, and a fresh portion of DMTrCl $(0.0350 \mathrm{~g}, 0.10$ $\mathrm{mmol}$ ) was added at $0{ }^{\circ} \mathrm{C}$. The reaction was further stirred at room temperature for an additional $4 \mathrm{~h}$ and then cooled in an ice bath and quenched with $\mathrm{MeOH}(100 \mu \mathrm{L})$. The reaction mixture was diluted with EtOAc $(10 \mathrm{~mL})$ and then washed with water $(10 \mathrm{~mL})$, saturated $\mathrm{NaHCO}_{3 \text { aq }}(10 \mathrm{~mL})$, and saturated $\mathrm{NaCl}(10 \mathrm{~mL})$. The combined aqueous layers were extracted with $30 \mathrm{~mL}$ of EtOAc, and the combined organic layers were dried on $\mathrm{Na}_{2} \mathrm{SO}_{4}$. Flash chromatography with EtOAc:isooctane:TEA 70:29:1 resulted in an off-white foam $(0.110 \mathrm{~g}, 0.164 \mathrm{mmol})$ in $79 \%$ yield. $R_{f}=0.43(\mathrm{DCM}: \mathrm{MeOH} 9: 1) .{ }^{1} \mathrm{H}$ NMR (MeOD, $300 \mathrm{MHz}): \delta 7.77(\mathrm{~d}, J=8.1 \mathrm{~Hz}, 1 \mathrm{H}), 7.08-7.34(\mathrm{~m}$, 9H), $7.27(\mathrm{~m}, 1 \mathrm{H}), 6.78(\mathrm{~d}, J=8.7 \mathrm{~Hz}, 4 \mathrm{H}), 6.20(\mathrm{~m}, 1 \mathrm{H}), 6.09(\mathrm{~d}, J=$ $3.2 \mathrm{~Hz}, 1 \mathrm{H}), 5.91(\mathrm{~d}, J=8.3 \mathrm{~Hz}, 1 \mathrm{H}), 5.25(\mathrm{~d}, J=8.1 \mathrm{~Hz}, 1 \mathrm{H}), 4.58$ $(\mathrm{dd}, J=5.7$ and $8.3 \mathrm{~Hz}, 1 \mathrm{H}), 4.16(\mathrm{~m}, 3 \mathrm{H}), 3.98(\mathrm{~m}, 1 \mathrm{H}), 3.64(\mathrm{~s}, 6 \mathrm{H})$, 3.24 (m, 2H). ${ }^{13} \mathrm{C}$ NMR (MeOD, $\left.125 \mathrm{MHz}\right): \delta$ 160.0, 160.3, 160.1, $154.1,152.7,145.8,143.0,142.6,136.9,136.7,131.4,129.5,129.0$, $128.1,114.3,111.3,107.4,103.0,88.4,88.3,87.2$, 72.4, 65.2, 57.6, 55.7, 38.0. ESI-MS: calcd for $\mathrm{C}_{36} \mathrm{H}_{36} \mathrm{~N}_{4} \mathrm{O}_{9}, 668.2$; found, 303.3 $[\mathrm{DMTr}]^{+}, 685.6\left[\mathrm{M}+\mathrm{NH}_{4}\right]^{+}$. HRMS (+ESI): calcd for $\mathrm{C}_{36} \mathrm{H}_{38} \mathrm{~N}_{4^{-}}$ $\mathrm{O}_{9} \mathrm{Na}\left(\mathrm{M}+\mathrm{Na}^{+}\right)$, 691.2374; found, 691.2375; calcd for $\mathrm{C}_{36} \mathrm{H}_{38} \mathrm{~N}_{4^{-}}$ $\mathrm{O}_{9 \mathrm{~K}}\left(\mathrm{M}+\mathrm{K}^{+}\right)$, 707.2114; found, 707.2125.

The DMTr-protected nucleoside $(0.079 \mathrm{~g}, 0.118 \mathrm{mmol})$ was coevaporated twice with toluene $(2 \times 1 \mathrm{~mL})$ and once with DCM $(1 \mathrm{~mL})$. The product was then dissolved in DCM $(1.2 \mathrm{~mL})$ and cooled to $0{ }^{\circ} \mathrm{C}$. DIPEA ( $65 \mu \mathrm{L}, 0.364 \mathrm{mmol})$ was added to the reaction, followed by 2-cyanoethyl $N, N$-diisopropylchlorophosphoramidite $(40 \mu \mathrm{L}, 0.179$ $\mathrm{mmol})$. The reaction mixture was stirred for $1.5 \mathrm{~h}$ at $0{ }^{\circ} \mathrm{C}$ and then quenched with $\mathrm{MeOH}(100 \mu \mathrm{L})$ and diluted with EtOAc $(20 \mathrm{~mL})$. The organic phase was washed once with saturated $\mathrm{NaHCO}_{3}$ aq $(20 \mathrm{~mL})$ and three times with saturated $\mathrm{NaCl}_{\mathrm{aq}}(3 \times 20 \mathrm{~mL})$, dried on $\mathrm{Na}_{2} \mathrm{SO}_{4}$, and concentrated by rotary evaporation. The residue was purified by flash chromatography using EtOAc:isooctane:TEA $55: 44: 1$, and the pure product was obtained as an off-white foam $(0.035 \mathrm{~g}, 0.060 \mathrm{mmol})$ in $50 \%$ yield. $R_{f}=0.45$ (isooctane: EtOAc 8:2). The ${ }^{1} \mathrm{H}$ NMR was complex and showed the presence of two diastereomers. ${ }^{31} \mathrm{P}$ NMR $\left(\mathrm{CDCl}_{3}, 121 \mathrm{MHz}\right): \delta 151.44,148.21$. ESI-MS: calcd for $\mathrm{C}_{45} \mathrm{H}_{53} \mathrm{~N}_{6} \mathrm{O}_{10} \mathrm{P}, 868.4$; found, 303.3 [DMTr] $^{+}$, $891.2[\mathrm{M}+\mathrm{Na}]^{+}$.

Materials and Methods for Oligonucleotides. Reagents for DNA synthesis were obtained from Glen Research. All RP-HPLC experiments with oligonucleotides were recorded on an Agilent 1100 system equipped with a Phenomenex Clarity column $(250 \times 4.6 \mathrm{~mm}$, $5 \mu \mathrm{m}$ ) at $50{ }^{\circ} \mathrm{C}$, with $0.1 \mathrm{M}$ TEAA (with $8 \% \mathrm{MeOH}$ ) and $\mathrm{MeOH}$ as mobile phase (linear gradient: $0-30 \% \mathrm{MeOH}$ in $15 \mathrm{~min}, 30-100 \%$ $\mathrm{MeOH}$ in $3 \mathrm{~min}$ ). The chromatograms were analyzed at $260 \mathrm{~nm}$. Enzymatic digestion reaction mixtures were analyzed on a Phenomenex Luna C18 column $(250 \times 4.6 \mathrm{~mm}, 5 \mu \mathrm{m})$ using the same method. Mass spectra of oligonucleotides were recorded on a quadrupole ion trap LC mass spectrometer (Thermofinnigan, San Jose, CA) equipped with electrospray ionization. Data were acquired in the negative ionization mode from $\mathrm{m} / z=100$ to $\mathrm{m} / z=1500$. The mass spectra were deconvoluted; i.e., the molecular weights of the compounds were reconstructed from the spectra using the Agilent LC/MSD ChemStation software (version A.08014). Cross-linking yields based on HPLC were calculated by comparing the peak area from the spectra before and after addition of NBS, taking into account the extinction coefficients calculated by the nearest-neighbor method. The extinction coefficient of the cross-linked duplex is taken to be 0.9 times the sum of the extinction coefficients of its composing sequences.

Synthesis of Modified DNA. All oligonucleotides were synthesized DMT-on using an ABI 394 DNA synthesizer at $1 \mu \mathrm{mol}$ scale. A standard synthesis protocol was used except for coupling of the modified residues. The synthesis column was removed from the DNA synthesizer for the introduction of the modified residues. For these manual couplings, a 0.06 $\mathrm{M}$ solution of the phosphoramidite in acetonitrile and a $0.1 \mathrm{M}$ solution of DCI in acetonitrile were dried on molecular sieves for about $20 \mathrm{~min}$. Small portions of the phosphoramidite solution $(0.4 \mathrm{~mL})$ and the DCI solution $(0.5 \mathrm{~mL})$ were then alternately pushed over the reaction column. The column was flushed with acetonitrile $(1 \mathrm{~mL})$, and a mixture of Cap A $(0.5$ $\mathrm{mL})$ and Cap B $(0.5 \mathrm{~mL})$ was pushed over the column, after which it was again flushed with acetonitrile $(1 \mathrm{~mL})$. The column was reinstalled on the DNA synthesizer, and automated synthesis was resumed.

Oligonucleotides were cleaved from solid support and deprotected by incubation at $55{ }^{\circ} \mathrm{C}$ overnight in concentrated aqueous ammonia. The synthesized DMTr oligonucleotides were deprotected and purified on SEP-PAK C18 cartridges (obtained from Waters).

$\mathrm{NaCl}$ was used from a $1 \mathrm{M}$ stock solution. Phosphate buffer was prepared in a $0.1 \mathrm{M}$ stock solution $\left(490 \mathrm{mg}\right.$ of $\mathrm{NaH}_{2} \mathrm{PO}_{4} \cdot \mathrm{H}_{2} \mathrm{O}$ and $548 \mathrm{mg}$ of $\mathrm{Na}_{3} \mathrm{PO}_{4} \cdot 12 \mathrm{H}_{2} \mathrm{O}$ in $50 \mathrm{~mL}$ of $\mathrm{H}_{2} \mathrm{O}$ ).

Thermal Denaturation Experiments. All UV experiments were recorded on a Varian Cary 300 Bio instrument equipped with a six-cell thermostatted cell holder. Melting curves were monitored at $260 \mathrm{~nm}$ with a heating rate of $0.3^{\circ} \mathrm{C} / \mathrm{min}$. The buffer contained $100 \mathrm{mM} \mathrm{NaCl}$ and $10 \mathrm{mM}$ phosphate buffer ( $\mathrm{pH}$ 7). Oligonucleotide concentration was $2 \mu \mathrm{M}$ for each strand. Melting temperatures were calculated from the first derivative of the heating curves using the Cary 300 Bio software.

Cross-Linking Reactions. The modified strands were mixed with their complements in equimolar amounts at $0.02 \mathrm{mM}$ concentration in $10 \mathrm{mM}$ phosphate buffer $(\mathrm{pH} 7)$ and $100 \mathrm{mM} \mathrm{NaCl}$ before annealing from $95{ }^{\circ} \mathrm{C}$ to room temperature. Temperatures during the whole reaction were kept constant in an Eppendorf thermomixer comfort at $25^{\circ} \mathrm{C}$. A stock solution of NBS ( 1 equiv $/ 2 \mu \mathrm{L}$ ) was freshly prepared, and to start the reaction, 1 equiv of NBS was added. This was repeated every 15 min until complete disappearance of the modified oligonucleotide. The reactions were monitored by RP-HPLC.

Aromatization of the 2'-Amido-furan-Modified ODN. NBS and salts were removed from the cross-linking reaction mixture using a $1 \mathrm{kDa}$ cutoff filter (Pall Life Sciences). The reaction mixture was diluted with $1 \mathrm{~mL}$ of $\mathrm{H}_{2} \mathrm{O}$ and centrifuged for $90 \mathrm{~min}$ at $7500 \mathrm{rpm}$. The residue was twice again redissolved in $1 \mathrm{~mL}$ of $\mathrm{H}_{2} \mathrm{O}$, and the same procedure was repeated. The residue was then taken in $\mathrm{H}_{2} \mathrm{O}$ and incubated at $50{ }^{\circ} \mathrm{C}$ (1-3 days) until complete conversion to the aromatized cross-linked duplex. The reaction was followed by RP-HPLC.

Gel Electrophoresis Experiments. A $20 \%$ polyacrylamide gel (acrylamide:bisacrylamide 19:1) with 1x TBE buffer and $7 \mathrm{M}$ urea was 
used for all analyses. The gel was prepared by dissolving $21.2 \mathrm{~g}$ of urea in $5 \mathrm{~mL}$ of 10x TBE buffer and $5 \mathrm{~mL}$ of $40 \%$ acrylamide. The solution was adjusted to $50 \mathrm{~mL}$ and slightly heated until urea was completely dissolved. After the solution was cooled by refrigeration, ammonium peroxodisulfate $(165 \mu \mathrm{L}, 100 \mathrm{mg} / \mathrm{mL})$ was added, followed by $N, N, N^{\prime}$, $N^{\prime}$-tetramethylethylenediamine. The solution was poured in between two glass plates $(20 \mathrm{~cm} \times 22 \mathrm{~cm})$ and allowed to polymerize for $30 \mathrm{~min}$, with $1 \mathrm{x}$ TBE used as the running buffer. The sample was mixed with formamide loading buffer, and the gels were run overnight at a voltage of $120 \mathrm{~V}$. The temperature of the gel was stabilized with a Julabo F12 circulator at $25{ }^{\circ} \mathrm{C}$. The power supply used for gel electrophoresis was a Consort EV202. Gels were stained with GelRed (VWR), and pictures were taken with an Autochemi imaging system (UVP).

Enzymatic Digestion. Crude SVPD was dissolved in $\mathrm{H}_{2} \mathrm{O}$ to a concentration of $0.0003 \mathrm{U} / \mu \mathrm{L}$ and centrifuged to remove insoluble contaminants. The supernatant was then used in the enzymatic degradation reactions.

The purified cross-linked aromatized duplex ODN3:ODN10b XLar $(0.4 \mathrm{nmol})$ was taken in $50 \mathrm{mM}$ Tris- $\mathrm{HCl}$ buffer, $\mathrm{pH} 8$, containig $10 \mathrm{mM}$ $\mathrm{MgCl}_{2}(100 \mu \mathrm{L})$. SVPD $(13.2 \mu \mathrm{L}, 0.0003 \mathrm{U} / \mu \mathrm{L})$ was added to the reaction mixture, and it was shaken overnight at $37^{\circ} \mathrm{C}$. The reaction was checked by RP-HPLC, and then $0.6 \mathrm{U}$ of alkaline phosphatase (from bovine intestinal mucosa, Sigma Aldrich) was added and the reaction mixture was further shaken at $37{ }^{\circ} \mathrm{C}$ for $1 \mathrm{~h}$. The reaction was again checked by RP-HPLC, after which the identity of the cross-linked dinucleoside could be confirmed by coinjection with dinucleoside 24 .

\section{ASSOCIATED CONTENT}

S Supporting Information. Supplementary data. This material is available free of charge via the Internet at http://pubs.acs.org.

\section{AUTHOR INFORMATION}

\section{Corresponding Author}

Annemieke.Madder@Ugent.be

\section{ACKNOWLEDGMENT}

M.O.d.B. is indebted to the Agency for Innovation by Science and Technology in Flanders (IWT) and the Special Research Fund of Ghent University (BOF-GOA2007, BOF-BAS 01B04405). We further thank the FWO Vlaanderen for financial support (FWO-KAN 1.5.137.09N, FWO-KAN 1.5.186-03).

\section{REFERENCES}

(1) Verma, S.; Eckstein, F. Annu. Rev. Biochem. 1998, 67, 99-134.

(2) Higuchi, M.; Kobori, A.; Yamayoshi, A.; Murakami, A. Biorg. Med. Chem. 2009, 17, 475-483.

(3) Young, D. D.; Lively, M. O.; Deiters, A. J. Am. Chem. Soc. 2010, 132, 6183-6193.

(4) Mangos, M. M.; Min, K. L.; Viazovkina, E.; Galarneau, A.; Elzagheid, M. I.; Parniak, M. A.; Damha, M. J. J. Am. Chem. Soc. 2003, $125,654-661$.

(5) Watts, J. K.; Choubdar, N.; Sadalapure, K.; Robert, F.; Wahba, A. S.; Pelletier, J.; Pinto, B. M.; Damha, M. J. Nucleic Acids Res. 2007, 35, 1441-1451.

(6) Nauwelaerts, K.; Fisher, M.; Froeyen, M.; Lescrinier, E.; Van Aerschot, A.; Xu, D.; DeLong, R.; Kang, H.; Juliano, R. L.; Herdewijn, P. J. Am. Chem. Soc. 2007, 129, 9340-9348.

(7) Shah, S.; Rangarajan, S.; Friedman, S. H. Angew. Chem., Int. Ed. 2005, 44, 1328-1332.

(8) Abe, N.; Abe, H.; Ito, Y. J. Am. Chem. Soc. 2007, 129, 1510815109.
(9) Jain, A.; Wang, G.; Vasquez, K. M. Biochimie 2008, 90, 11171130.

(10) Rahman, S. M. A.; Seki, S.; Obika, S.; Yoshikawa, H.; Miyashita, K.; Imanishi, T. J. Am. Chem. Soc. 2008, 130, 4886-4896.

(11) Datta, B.; Armitage, B. A. J. Am. Chem. Soc. 2001, 123, 96129619.

(12) Nakane, M.; Ichikawa, S.; Matsuda, A. J. Org. Chem. 2008, 73, 1842-1851.

(13) Osako, M. K.; Tomita, N. A.; Nakagami, H.; Kunugiza, Y.; Yoshino, M.; Yuyama, K.; Tomita, T.; Fac, H.; Ogihara, T.; Morishita, R. J. Gene Med. 2007, 9, 812-819.

(14) Glick, G. D. Biopolymers 1998, 48, 83-96.

(15) Blose, J. M.; Proctor, D. J.; Veeraraghavan, N.; Misra, V. K.; Bevilacqua, P. C. J. Am. Chem. Soc. 2009, 131, 8474-8484.

(16) Gerdt, J. P.; Miduturu, C. V.; Silverman, S. K. J. Am. Chem. Soc. 2008, 130, 14920-14921.

(17) Fang, Q. M.; Noronha, A. M.; Murphy, S. P.; Wilds, C. J.; Tubbs, J. L.; Tainer, J. A.; Chowdhury, G.; Guengerich, F. P.; Pegg, A. E. Biochemistry 2008, 47, 10892-10903.

(18) Wilds, C. J.; Noronha, A. M.; Robidoux, S.; Miller, P. S. J. Am. Chem. Soc. 2004, 126, 9257-9265.

(19) Noll, D. M.; Noronha, A. M.; Miller, P. S. J. Am. Chem. Soc. 2001, 123, 3405-3411.

(20) Dutta, S.; Chowdhury, G.; Gates, K. S. J. Am. Chem. Soc. 2007, $129,1852-1853$.

(21) Elmquist, C. E.; Stover, J. S.; Wang, Z. W.; Rizzo, C. J. J. Am. Chem. Soc. 2004, 126, 11189-11201.

(22) Lindahl, T. Nature 1993, 362, 709-715.

(23) Dronkert, M. L. G.; Kanaar, R. Mutat. Res.-DNA Repair 2001, 486, 217-247.

(24) Sczepanski, J. T.; Jacobs, A. C.; Greenberg, M. M. J. Am. Chem. Soc. 2008, 130, 9646-9647.

(25) Rajski, S. R.; Williams, R. M. Chem. Rev. 1998, 98, 2723-2795.

(26) Noll, D. M.; Mason, T. M.; Miller, P. S. Chem. Rev. 2006, 106, 277-301.

(27) Noll, D. M.; Noronha, A. M.; Wilds, C. J.; Miller, P. S. Front. Biosci. 2004, 9, 421-437.

(28) Wilds, C. J.; Palus, E.; Noronha, A. M. Can. J. Chem.-Rev. Can. Chim. 2007, 85, 249-256.

(29) Wilds, C. J.; Noronha, A. M.; Robidoux, S.; Miller, P. S. Nucleosides Nucleotides Nucleic Acids 2005, 24, 965-969.

(30) Li, H. Y.; Qiu, Y. L.; Moyroud, E.; Kishi, Y. Angew. Chem., Int. Ed. 2001, 40, 1471-1475.

(31) Dooley, P. A.; Tsarouhtsis, D.; Korbel, G. A.; Nechev, L. V.; Shearer, J.; Zegar, I. S.; Harris, C. M.; Stone, M. P.; Harris, T. M. J. Am. Chem. Soc. 2001, 123, 1730-1739.

(32) Le Gac, S.; Rickling, S.; Gerbaux, P.; Defrancq, E.; Moucheron, C.; Kirsch-De Mesmaeker, A. Angew. Chem., Int. Ed. 2009, 48, 11221125.

(33) Hattori, K.; Hirohama, T.; Imoto, S.; Kusano, S.; Nagatsugi, F. Chem. Commun. 2009, 6463-6465.

(34) Angelov, T.; Guainazzi, A.; Scharer, O. D. Org. Lett. 2009, 11, 661-664.

(35) Yoshimura, Y.; Fujimoto, K. Org. Lett. 2008, 10, 3227-3230.

(36) Qiu, Z. H.; Lu, L. H.; Jian, X.; He, C. J. Am. Chem. Soc. 2008, 130, 14398-14399.

(37) Kocalka, P.; El-Sagheer, A. H.; Brown, T. Chembiochem 2008, 9, $1280-1285$.

(38) Hong, I. S.; Ding, H.; Greenberg, M. M. J. Am. Chem. Soc. 2006, $128,2230-2231$.

(39) Alzeer, J.; Scharer, O. D. Nucleic Acids Res. 2006, 34, 44584466.

(40) Hatano, A.; Makita, S.; Kirihara, M. Bioorg. Med. Chem. Lett. 2004, 14, 2459-2462.

(41) Nagatsugi, F.; Tokuda, N.; Maeda, M.; Sasaki, S. Bioorg. Med. Chem. Lett. 2001, 11, 2577-2579.

(42) Alefelder, S.; Sigurdsson, S. T. Biorg. Med. Chem. 2000, 8, 269273. 
(43) Halila, S.; Velasco, T.; De Clercq, P.; Madder, A. Chem. Commun. 2005, 936-938.

(44) McGee, D. P. C.; VaughnSettle, A.; Vargeese, C.; Zhai, Y. S. J. Org. Chem. 1996, 61, 781-785.

(45) Kirschenheuter, G. P.; Zhai, Y. S.; Pieken, W. A. Tetrahedron Lett. 1994, 35, 8517-8520.

(46) Ariza, X.; Urpi, F.; Viladomat, C.; Vilarrasa, J. Tetrahedron Lett. 1998, 39, 9101-9102.

(47) Lin, F. L.; Hoyt, H. M.; van Halbeek, H.; Bergman, R. G.; Bertozzi, C. R. J. Am. Chem. Soc. 2005, 127, 2686-2695.

(48) Verheyden, J. P. H.; Wagner, D.; Moffat, G. j. J. Org. Chem. 1971, 36, 250-254.

(49) Jin, S. X.; Miduturu, C. V.; McKinney, D. C.; Silverman, S. K. J. Org. Chem. 2005, 70, 4284-4299.

(50) Johnson, D. C.; Widlanski, T. S. Org. Lett. 2004, 6, 4643-4646.

(51) Standard protocol for manual coupling: a solution of DCI in acetonitrile is added to the solution of the modified phorphoramidite. This mixture is then applied on the column containing the growing oligonucleotide chain.

(52) Al-Rawi, S.; Ahlborn, C.; Richert, C. Org. Lett. 2005, 7, 15691572.

(53) Peterson, L. A. Drug Metab. Rev. 2006, 38, 615-626.

(54) Vu, C. C.; Peterson, L. A. Chem. Res. Toxicol. 2005, 18, 10121017.

(55) Byrns, M. C.; Vu, C. C.; Peterson, L. A. Chem. Res. Toxicol. 2004, 17, 1607-1613.

(56) Bohnert, T.; Gingipalli, L.; Dedon, P. C. Biochem. Biophys. Res. Commun. 2004, 323, 838-844.

(57) Byrns, M. C.; Predecki, D. P.; Peterson, L. A. Chem. Res. Toxicol. 2002, 15, 373-379.

(58) Gingipalli, L.; Dedon, P. C. J. Am. Chem. Soc. 2001, 123, 2664 2665.

(59) Kobayashi, Y.; Nakano, M.; Kumar, G. B.; Kishihara, K. J. Org. Chem. 1998, 63, 7505-7515.

(60) Stevens, K.; Madder, A. Nucleic Acids Res. 2009, 37, 1555-1565.

(61) Robertson, A.; Philp, D.; Spencer, N. Tetrahedron 1999, 55, $11365-11384$.

(62) Verheyden, J. P. H.; Wagner, D.; Moffat, G. J. J. Org. Chem. $1971,36,250-254$. 